\title{
Divine Wrath in Ancient Egypt
}

\author{
AmGad JosePH
}

\begin{abstract}
This article aims at examining the theme of divine wrath according to Egyptian religious beliefs, in connection with deities and worshippers. It is a matter of theological concern to examine the theme of divine wrath in various texts describing the rage of deities. The paper thoroughly discusses the theme of divine wrath, its addressees, effects, purposes, provocations, and the possibility of avoidance and pacification, as well as the linguistic expressions of wrath. It discusses the notion of wrath, its perceived consequences and infliction on the deities, living humans and the deceased. It also examines divine wrath in relation to the experience of suffering and affliction as well as that of protection and welfare. The analysis provides information on the core of the Egyptian religion investigated from the perspective of wrath.
\end{abstract}

Keywords: ancient Egypt, divine wrath, religion, mythology

Amgad Joseph, Faculty of Tourism and Hotel Management, Helwan University, Cairo; amgadjoseph@yahoo.com

The theme of divine wrath has been neglected in scholarly work on the theology of the Egyptian deities. It is not fully examined despite its prevalence in various Egyptian texts and its association with other crucial doctrines, and notably the nature of deities. Thus, divine wrath should be given particular attention as a distinctive theological matter to reveal its character and purpose.

The subject of the present paper, namely divine wrath in Egyptian (dynastic and GraecoRoman) sources, is inspired by two remarks made by Henri Frankfort and Val Hinckley Sederholm, in 1948 and 2006, respectively. Frankfort argues that the 'Egyptian religion ignored the theme of the wrath of god'. ${ }^{1}$ Thus, he states that the theme of divine wrath is rarely, if ever, found in the Egyptian texts. He even asserts that this theme is practically unknown in Egyptian literature, since the Egyptian is not an offender whom god discards, but an ignorant person who is disciplined. ${ }^{2}$ Sederholm, on the other hand, argues that divine

\footnotetext{
1 Frankfort 1948: 269.

2 Frankfort 1949: 77.
} 
wrath is ambiguous as a perennial theme, and only by the end of the New Kingdom does it serve as a means of attack. ${ }^{3}$

The Egyptian language provides ample words with meanings of wrath, wrathful, rage, raging, anger, angry, fury, and furious, namely: 'špt', 'šnt', 'sšn', ' $3 d$ ', ' ' $3 t$ ', ' $d \check{s} r w$ ',

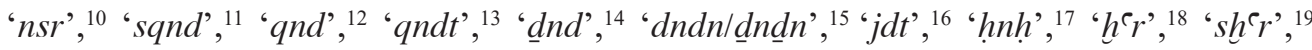
' $n s ̌ n y ',{ }^{20}$ ' $t m s$ ', ${ }^{21}$ ' $n h d$ ', ${ }^{22}$ and ' $k h 3$ '. ${ }^{23}$ The conception of the divine wrath is known in ancient Egypt as early as the period of the Pyramid Texts ${ }^{24}$ and throughout the Egyptian history. Thus, divine wrath is stated in a variety of texts on different monuments.

The present article raises the debatable hypothesis as to whether each deity has his/her own triggers, and provocations, which could make him/her wrathful or not. Further, it wonders if divine wrath is attributed to the deity's spheres of action, influence and roles in mythology. Finally, it examines the effects, purposes and consequences of divine wrath on addressees. The methodology followed in this article is to analyse attestations in which the deities are presented as furious and angry with the living humans, the deceased or with each other. This methodology aims at classifying these attestations in accordance with consistent groups of deities, to analyse and compare them.

\section{DEITIES AS INFLICTORS OF WRATH}

Consistent with ancient Egyptian religious belief, divine wrath is dreadful and, if not calmed in time, can be directed towards the god's own town and worshippers. In this context,

3 Sederholm 2006: 176.

$4 \mathrm{~Wb}$ IV, 453, 10-15.

5 Wb IV, 518, 11; Newberry 1893: 7-8; Faulkner 1972: 269.

$6 \mathrm{~Wb}$ IV, 293, 4.

7 The word ' $3 d$ ' also means 'to be aggressive', and 'to be angry'; see: $W b$ I, 24, 18-19; Wilson 1997: 27.

8 For '3t', 'moment of rage', see: $W b$ I, 22, 19; Allen 2010: 455. For '3t', 'moment of attack', see: $W b$ I, 11 ; Wilson 1997: 25 .

$9 \mathrm{~Wb}$ V, 490, 7-13; Buck 1935: 21.

${ }^{10}$ It is used as a verb that means 'to make rage'; see: Faulkner 1972: 140; Jéquier 1911: 12, 2.

11 For 'sqnd', 'to enrage', see: Faulkner 1972: 250; Wb IV, 306, 8-9.

12 For ' $q$ nd', 'to rage, to be angry', see: $W b$ V, 56, 16-57, 1-12; Wilson 1997: 1064-1065. For 'qnd', 'baboon', see: Störk 1982: 917.

13 P. Chester Beatty I, rt. 1, 12-2, 1; Lichtheim 1976: 215.

14 Allen 2010: 431.

$15 \mathrm{~Wb} \mathrm{~V}, 470-471$; Wilson 1997: 1202. It is a form of older ' $d n d$ '; see: $W b \mathrm{~V}, 579$, 1. For 'dndn', 'wrath', see: $W b$ V, 470; Edwards 1960: 108, n. 24; Lesko, Lesko 2002: 252 (vol. 2).

16 Faulkner 1972: 35; Couyat, Montet 1912: 114, 7.

17 For 'hnh', 'anger', see: Lesko, Lesko 2002: 319 (vol. 1).

18 For ' $h$ 'r', 'to be furious, to rage', see: KRI II, 119, 7-10; Wb III, 244, 2-7; Urk. IV, 8, 13; $1290,7$.

19 For 'sh'r', 'to enrage', see: $W b$ IV, 238, 3.

${ }^{20}$ Faulkner 1972: 140; $W b$ II, 340, 11-30. For 'nšny', 'fury', see: Gardiner 1932: 6, 2, x+18-19. For 'nšny', 'to rage', see: Gardiner 1911: 15, 2; KRI II, 151, 4; V, 64, 13, 35, 13, 42, 3, 79, 13, see also: Wilson 1997: 550.

${ }^{21}$ For other meanings of 't $t m s$ ', see: Lefebvre 1949: 74-75; Zandee 1977: 292-293; Goyon 1972: 123 (§ 345).

22 Wb II, 288, 2-3; Hannig 2006: 1309.

${ }^{23}$ For ' $k h 3$ ', 'rage furiously', see: $W b \mathrm{~V}, 137$; Faulkner 1972: 287; Blackman, Fairman 1944: 19.

${ }^{24}$ Faulkner 1969: 231. 
the discussion of the divine wrath infliction is crucial for this study with the purpose of revealing its addressees, motivations, effects, purposes, provocations and consequences.

\section{ANONYMOUS GOD}

\section{ATTESTATIONS}

Although specific gods are known as inflictors of wrath, the spells of the Pyramid Texts, Coffin Texts, Book of the Dead and other texts give a number of incantations where the inflictor of wrath is an anonymous god. In utterance 576 of the Pyramid Texts: The king will not putrefy, he will not rot, this king (i.e. Pepi) will not be cursed by your anger, you gods ( $n$ šnjw Ppy pn jn dnd=tn ntrw). ${ }^{25}$ In spell 719 of the Coffin Texts, an anonymous god vents the wrath of his heart on the deceased through his words; it reads: To dispel anger in the heart of a god against me (dr spt $m$ jb ntr $r=j$ ). Woe to you, O you who send out power and who preside over all mysteries. See a word is spoken against me by a god who is angry with me ( $m k \underline{d} d$.tw $m d w r=j$ jn ntr špt(.w) $r=j$ ), but wrongdoing is washed away, and it falls into the hands of the Lord of Justice. ${ }^{26}$

In spell 672 of the Coffin Texts, the deceased has the ability to annihilate the rage of any god saying: It is $N$., who cuts off the raging of any god, any spirit or any dead (hsq(w) $n \check{s} n n(y) n t r n b$ 3h $n b m(w) t n b)$ and he ferries himself over as $N$ in his (own) shape. ${ }^{27}$

Chapter 14 in the Book of the Dead is a formula for removing fury from the heart of the god against the deceased $(r n d r \check{s} p t$-jb $m$ jb $n n t r r N) .{ }^{28}$ In this chapter, the deceased says: Behold, a statement has been made (against) me by a god who is angry with me (mk $m d w$ jn ntr špt (.w) $r=j) .{ }^{29}$ In the same chapter, the deceased addresses this god as the Lord of Offerings, with the aim of averting all the anger in the god's heart against him saying: $O$ Lord of Offerings, great ruler, behold I have brought to you a propitiation-offering so that you may live on it ( $m k j n . n=j n=k$ shtpyw $~ n h(w)=k j m=f)$ and that I live on it; be gracious to me, and avert all the anger that is in your heart against me ([htp $n=j] d r \breve{s p t}$ $n b(t) n t y(t) m j b=k r=j) .{ }^{30}$

In an anonymous Twenty-sixth Dynasty tomb inscription at el-Hasaia, ${ }^{31}$ any living individual who does not recite the $h t p-d j-n s w$ or magical offering formula will be the target of divine wrath. This is attested in the text, which reads: As for the one who does not say this (i.e. htp dj nsw), he [will be for] his local god's rage (jr tm $\underline{d} d n n j w=f[r] d n d n n n t r=f$ njwty), and (for) the king's striking down. ${ }^{32}$ On the other hand, neglecting the festival of any god provokes his divine wrath. This is stated in the Twenty-second Dynasty Maxims

25 PT 576, § 1509b; Faulkner 1969: 231.

${ }^{26}$ CT VI, 347a-e [719]; Faulkner 1977: 272; Carrier 2004b: 1628-1629.

${ }^{27}$ CT VI, 300i [672]; Faulkner 1977: 242; Carrier 2004b: 1532-1533.

28 Faulkner 1985: 17; Quirke 2013: 31.

29 Allen 1974: 11-12; Faulkner 1985: 39.

30 Allen 1974: 11-12; Carrier 2009: 37-38. Human anger emanates from the heart as well; see: Lichtheim 1980: 212 .

31 Edel 1984: 190.

32 Nordh 1996: 165; Edel 1984: 190. 
of Ani (Papyrus Boulaq 4); it reads: Celebrate the festival (for) your god and repeat it (at) its proper time, god is angry (when) he is neglected (jrt $h b(n) n t r=k w h m=k s(r) t r=f$ qnd $n t r(h r)$ thjw.tw=f), put up witnesses after you have offered, the first time of doing it. When one comes to check your inventory (?), have them enter you in the roll. ${ }^{33}$

\section{ADDRESSEES}

In the above-mentioned spells of the Pyramid Texts, the Coffin Texts, and the Book of the Dead, the addressees include the dead king and any deceased. In the threat formula of el-Hasaia inscription, and in the Maxims of Ani, the addressee is any living person.

\section{INFLUENCE AND PURPOSE}

In utterance 576 of the Pyramid Texts, the statement that the king will not be cursed by the god's anger is associated with the fact that he will not putrefy, and he will not rot. ${ }^{34}$ This implies that the putrefaction of the king could be a consequence of the god's anger. Thus, the purpose of anger is to condemn and judge the king in the afterlife.

In spell 719 of the Coffin Texts and chapter 14 in the Book of the Dead, a word is spoken against the deceased by a god who is angry with him. This demonstrates the condemnation and judgement of the deceased by this god in the afterlife. Therefore, the deceased states that his judgement falls into the hands of the Lord of Justice, as he wishes to be justified.

In the tomb inscription of el-Hasaia, several consequences follow the threat of the local god's rage. The text states that the trespasser will not be remembered among akhs, his name will not be pronounced in the land forever and ever, there will not be invocation-offering for him, there is not his burial in the western necropolis, he will $b[$ urn tog]ether with the criminals, after Thoth [has] planted an obstacle against him, his face will be spat upon..$^{35}$ These threats show that they are posed by an angry god, with the purpose of punishing the trespasser in the afterlife.

\section{POSSIBILITY OF AVOIDANCE AND PACIFICATION}

It is evident that the dead king can avoid divine wrath, as he will not be cursed by the anger of gods. The caption of both spell 719 of the Coffin Texts and chapter 14 in the Book of the Dead 'To dispel anger in the heart of a god', clearly demonstrates the possibility of avoiding the anger of god. Furthermore, the statement wrongdoing is washed away, and it falls into the hands of the Lord of Justice ( $m h(. w)$ jsft hr=s hr `wy nb M`3t), in spell 719 , emphasises that possibility. In spell 672, cutting off the god's rage, describes how the deceased can ward off and annihilate the malign divine wrath of any god. In chapter 14 in the Book of the Dead, the deceased addresses the angry god as the Lord of Offerings and brings to him a propitiation offering with the purpose of pacifying him and averting all the anger in the god's heart against him.

\footnotetext{
${ }_{33}$ Maxims of Ani 3, 3-4 = P. Boulaq 4, 16, 3-4; Gardiner 1959: 13; Lichtheim 1976: 136; Quack 1994: 90-91; Eyre 2013: 203, n. 263.

${ }^{34}$ PT 576, §§ 1501b, 1509b; Faulkner 1969: 231.

${ }^{35}$ Edel 1984: 190.
} 
In the Maxims of Ani, neglecting the celebration and repetition of the god's festival provokes his anger. The latter can be avoided through putting up witnesses, when the celebrant offers to the god for the first time. As for the tomb inscription at el-Hasaia, it demonstrates that the rage of the local god is inevitable.

\section{LINGUISTIC EXPRESSIONS}

The expression ' $n$ šnjw Ppy pn jn $\underline{d} n d=\underline{t} n$ ntrw' shows that the anger of the gods could be a curse on the dead king. This evokes the tomb curses, which threaten the trespassers with the wrath of gods. ${ }^{36}$ The curse suggests that the god will make the cursed one suffer his wrath and punishment. Dispelling or removing anger from the heart of a god ' $d r s p t^{37} m j b$ $n t r, d r \check{s} p t n b(t) n t y(t) m j b$ and $d r \check{s} p t-j b m$ jb $n n t r$ ' against the deceased demonstrates that this anger is something malign and unpleasant. Therefore, the verb ' $d r$ ' is also used in connection with removing evil, as Thoth is the one who drives away evil ' $d r \underline{d} w t$ '..$^{38}$ The verb is also used to mean 'subdue (enemies)' and 'repress (wrongdoer)'. ${ }^{39}$ Its use may also find an explanation in statements, which express the removal of psychological pain from the heart, ${ }^{40}$ and physical pain from the body, ${ }^{41}$ as pain and anger are both negative feelings.

Cutting off the rage of any god ' $h s q(w) n s ̌ n n(y) n t r r n b$ ' also demonstrates that the god's rage is malign, dreadful and should be annihilated. It evokes the decapitation ' $h s q$ ' of Seth and his followers in the Pyramid Texts. ${ }^{42}$ Further, a text in the temple of Edfu states that Seth the wrathful ' $d n d n$ ' is cut into pieces in Djeba. ${ }^{43}$

The expression, 'he [will be for] his local god's rage' ' $j r$ tm $d d n n j w=f[r] d n d n n n t r=f$ njwty', suggests that the addressee will become overwhelmed with the divine rage. This evokes a text on the Twenty-sixth Dynasty Donation Stela of Necho II (BM 1655); it reads: As for the one who will displace them (i.e. allocation of land), he will be $<$ for $>$ the fiery blast of Sekhmet and $<$ for $>$ the heat of Bastet $\left(j w=f<r>h h n\right.$ Shmt $<r>$ šmm $n$ B3stt). ${ }^{44}$

${ }^{36}$ Tomb of Djefay-Hapy, Siut I, 223-224 = Urk. VII, 53, 7-13; see: Griffith 1889: 9-10, Pl. IV; Frandsen 1998: 987, nn. 45-46.

${ }^{37}$ For 'špt-jb', 'anger', see: Faulkner 1978: 265; Wb IV, 453, 16-454, 4.

${ }^{38}$ Faulkner 1985: 181; Quirke 2013: 468.

${ }^{39}$ Faulkner 1972: 314.

${ }^{40}$ In the Ptolemaic Lamentations of Isis and Nephthys, Papyrus Berlin 3008, Nephthys addresses Osiris saying: You may drive out all the pain which is in our hearts $(d r=k 3 h w n b$ nty $m$ jbw=n)! See: P. Berlin 3008, 3, 4-3, 7; Faulkner 1934: 339, Pl. 2; Lichtheim 1980: 118.

${ }^{41}$ In a text on the Twenty-fifth Dynasty stelophorous statue of Mentuemhat at Cairo Museum (CG 42237), he addresses Amun saying: I bow down to your name, may it be my physician, may it remove my body's illness, may it drive pain away (from me) ( $d r=f$ mnt $\left.n w h^{\ulcorner} w=j s h r j=f n w h d\right)$; see: Lichtheim 1980: 30.

${ }^{42}$ PT 367, § 635c-d; Faulkner 1969: 121; Carrier 2010a: 314-315. It also evokes the decapitation of Apophis in the text of the second chapter of Felling Apophis, the enemy of Re in Papyrus Bremner Rhind, as it reads: Your head will not join to your body ( $n n t s$ t $\left.p=t n m h^{\varsigma}=t n\right)$; see: P. Bremner Rhind (BM 101888), 25, 13; Faulkner 1933: 53.

${ }^{43}$ Wilson 1997: 1202; Edfou VI, 11, 7.

44 Jansen-Winkeln 2014: 286; Nordh 1996: 82. For fire as a metaphor for divine fury, and one of the most common attributes of Sekhmet, see: Leahy 1982-1983: 84, n. u. 


\section{CREATOR GODS}

\section{ATTESTATIONS}

Amun-Re is known as a wrathful god who becomes angry at evil and holds life and death in his hands. ${ }^{45}$ Therefore, he has an ambivalent ${ }^{46}$ character with contradictory aspects. On the Nineteenth Dynasty votive stela of Nebre (Berlin Museum 20377), the god's wrath is stated as he is the lord of Thebes who spends a whole day not in anger ( $n b n$ W3st hrw $\underline{d} r=f$ qnd.tw), his wrath passes in a moment, and none remains (jry qnd=f $m \mathrm{~km} \mathrm{n} 3 \mathrm{t} n n$ spyt). ${ }^{47}$ The text on this stela demonstrates that the visit of Nebre to the temple of Amun-Re was not only to present thanksgivings to the god, but also to avoid his wrath.

Amun's wrath is compared to that of a lion in the New Kingdom Papyrus Leiden I 350, where he is the Raging lion with furious claws ( $m 3 j$ h̆s’ nšny ' $n w t$ ), who blows up the blood of his attackers in a moment. ${ }^{48}$ On the Twenty-first Dynasty Banishment Stela (Louvre C. 256), the First Prophet of Amun-Re, Menkheperre, addresses the great god adoring his lord like a father, saying: Great of wrath (wr b3w), ${ }^{49}$ he is more powerful than Sekhmet (shm sw r Shmt), like the fiery blast in a storm wind.$^{50} \mathrm{He}$ also says about the god: Who can resist your wrath (jn-nym $t 3 y=f \breve{s} p t=k$ ), who can divert the fury of your power? (js $d r[=f n \check{s} n y(?)] b 3 w=k$ ) Will you listen to my voice today and be forgiving toward the quarrelsome servants whom you banished to the oasis, and let them be brought back to Egypt? Then the great god nodded in agreement very fervently. ${ }^{51}$

Individuals may appeal to the god to inflict his wrath on those who hurt them. This is attested in the Twenty-first Dynasty settlement text of Henuttawy, dating to the reign of Amonemope or Siamon. ${ }^{52}$ It states that the second prophet of Amun Tchaynefer appeals to Amun-Re asking him to inflict his wrath on any military commander and his relatives, who would cause any harm, injury or evil to Henuttawy. He addresses the great god saying: Will you inflict your great and heavy wrath $(j w=t n$ jr $n[3 y=t n] b 3 w$ (3w dns[w]) upon them. ${ }^{53}$

Amun-Re is attested as venting his wrath on the tomb robbers in threat formulae. On the base of the Twenty-first Dynasty statue of Herihor (Cairo Museum JE 42190), ${ }^{54}$ the general and high priest at Karnak, he addresses the tomb robbers, saying: As for

\footnotetext{
45 Assmann 1995: 203; Bleeker 1969: 52.

46 For texts showing the ambivalent characters of deities in wrath and grace, see: Assmann 2001: $232-233$.

47 Lichtheim 1976: 107.

48 P. Leiden I 350, rt. V, 7; Zandee 1947: 94; 1966: 29; Assmann 1975: 319.

$49 \mathrm{~Wb}$ I, 413, 2. For ' $b 3 w$ ' as a noun denoting not just might but anger, especially of a god, cf. Caminos 1958:
} $122, \S 192$ (i).

${ }^{50}$ Banishment Stela, Louvre C. 256, 1. 14; Ritner 2009: 125, 127, see also: Assmann 1975: 71; 1995: $203-$ 204.

51 Banishment Stela, Louvre C. 256, 11. 15-16; Beckerath 1968: 7-36. For further information about the stela, see: Thijs 2011: 163-181, Figs 1-7. Ritner translates this text as who will withstand your displeasure, or will dispel [the fury of] your wrath; see: Ritner 2009: 125, 128.

52 The text is inscribed on the X Pylon of the great temple of Amun-Re at Karnak, see: PM II², 187 (580).

53 Ritner 2009: 140, 142, 1. 33. For the heavy wrath of Amun, see: Caminos 1964: 74, 76-77.

54 Lefebvre 1926: 63-68; Kitchen 1986: 248, § 209. 
any man who will remove this statue from its place, after many years, he is subject to the wrath of Amun, Mut ${ }^{55}$ and Khonsu (jw=f $m$ b3w $n$ Imn Mwt Hnsw). His name shall not exist in the land of Egypt. May he die of hunger and of thirst. ${ }^{56} \mathrm{In}$ a similar context, on a Luxor stela dating to the Twenty-second Dynasty, Amun threatens those who shall move the stela, saying: [As for anyone(?) who shall] move this stela, (namely) (they) against whom Amun<-em->Opet has extended his hand in his capacity of the Raging One $($ dnd $) .{ }^{57}$

In the Roman Story of prince Setne Khaemwas (Setne II) ${ }^{58}$ the king sent for the chieftain of Nubia, and the boy Si-Osire son of Khaemwas who came to the centre of the court and stood with the chieftain of Nubia. Then he addressed him saying: You who came down to Egypt, the beautiful garden of Osiris, the footrest of Re-Harakhti, the beautiful horizon of Shay saying, 'I will take [its] shame to the land of Nubia,' may the wrath of Amun, your god, smite you! ${ }^{59}$

The aspect of the raging sun god Re is embodied in Nsrt, the 'flaming goddess', his cobra, who spits her fiery breath against his enemies. ${ }^{60} \mathrm{Re}$ in his rage can take the shape of a predatory bird, especially a hawk. This form embodies the aggressive and overpowering aspect of the sun in the moment of its most intense heat and radiance. ${ }^{61}$ Therefore, the anger of Re-Harakhti, who takes a hawk-shape, is stated in the New Kingdom Contendings of Horus and Seth (Papyrus Chester Beatty I). ${ }^{62}$ Thus, Re-Harakhti became exceedingly angry (R'-hr-3hty (hr) qndt $r$ jqr ${ }^{63} s p 2$ ), for it was Re-Harakhti's wish to give the office (of Osiris) to Seth. ${ }^{64}$ Furthermore, The All-Lord (Re-Harakhti) was silent for a long moment for he was angry with the Ennead (jw $=f$ qnd $r t 3 y P s \underline{d} t),{ }^{65}$ as they make decisions on their own regarding the case of Horus and Seth. The All-Lord became angry at Horus (qnd $r \mathrm{Hr}$ ), because he believes that Horus does not deserve the office of Osiris.

The wrath of Re against Apophis is stated in a number of texts. A text on the Thirteenth Dynasty Metternich Stela (MMA 5085) ${ }^{66}$ addresses Re for protection against the confederates of Apophis; it reads: A great cry is in the mouth of every god and every goddess, since the great gods are in mourning because of the injury that you have inflicted $O$ enemy and evildoer. Behold, Re is raging and furious because of it ( $\left.m k R^{\ulcorner} n s ̌ n ~ h{ }^{\ulcorner} r h r=s\right)$, and he has given the order to carry out your slaughter. Back, $O$ enemy ( $w d=f j r t ~ s ̌ c d=k h 3=k s b j) !^{67}$

\footnotetext{
55 Mut was identified with Sekhmet who had to be pacified constantly; see: Schneider 2013: 252.

56 Ritner 2009: 82.

57 Daressy 1894: 125; Morschauser 1991: 223.

$58 \mathrm{He}$ is the fourth son of Ramesses II.

59 The text is written on the verso of P. British Museum 604; see: Lichtheim 1980: 144, 147.

60 Assmann 1995: 53.

61 Assmann 1995: 53.

62 P. Chester Beatty I; Lichtheim 1976: 214-216.

${ }^{63}$ For 'r jqr', 'exceedingly', see: Faulkner 1972: 31-32.

64 P. Chester Beatty I, rt. 1, 12-2, 1; Lichtheim 1976: 215.

65 P. Chester Beatty I, rt. 1, 9; Lichtheim 1976: 214.

66 Metternich Stela V, 47-48; see: Sander-Hansen 1956: 33.

67 Ritner 2009: 71-72; Jansen-Winkeln 2007: 414, no. 45.27.
} 
The wrath of Re against a scorpion is stated in a magical spell, on the Ptolemaic statue of Djedher (Cairo Museum, JE 46341), for conjuring a cat goddess, plausibly Bastet, ${ }^{68}$ daughter of Re. The sun god is entreated to rescue his daughter reading: $O R e$, come to your daughter for a scorpion has stung her on a lonely road! Her cries have reached heaven. Come to your daughter! The poison has entered her body and it has spread in her flesh. She has put her mouth to the ground. See the poison has entered her body! Do come with your power, with your rage ( $m$ dndn=k), with your wrath $(m$ dšrw $=k) .{ }^{69}$

The rage of $\mathrm{Re}^{70}$ can be inflicted on a town or land. Thus, when the sun god rages on a land, he expels Maat from it. ${ }^{71}$ The Ptolemaic Instruction of Ankhsheshonq (Papyrus British Museum 10508) demonstrates the way in which Re is angry with a land ' $p 3 R^{\top} h^{\complement} r r t s^{\prime}$, where innocent people experience false accusations, imprisonment and oppression. On the other hand, Re and the Ennead became exceedingly angry in the Ptolemaic Papyrus Jumilhac, because Nemty cut off the head of Hathor. The text of this papyrus reads: Someone came to commit, in the Aphroditopolis nome, this crime, which took place in the temple of Hathor, lady of mfk3t. Re and the Ennead, after hearing it, they were exceedingly angry

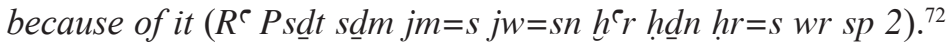

\section{ADDRESSEES}

It is evident that Amun-Re vents his wrath on private individuals. He inflicts his wrath on those who cause harm, injury or evil to others as well as the trespassers and tomb robbers. On the other hand, Re inflicts his wrath on lands. Re-Harakhti, a form of the sun god, addresses his anger to gods, Thoth, the Ennead and Horus, as he wished to give the office of the king to Seth instead of Horus. Re also addresses his rage and fury towards Apophis, and a poisonous scorpion. He becomes angry at oppression, crimes and evildoing.

\section{INFLUENCE AND PURPOSE}

The wrath of Amun-Re may not hurt those who pacify and entreat him, as he turns from his anger, to be merciful. However, his wrath is destructive, malign, irresistible, and unbearable and it may cause injuries to his attackers. The god's wrath aims at punishing the trespassers of tombs and those who violate the norms of Maat. In the stela of Nebre, Amun-Re inflicts his wrath as a punishment on the draftsman Nakhtamun, who lay sick unto death as he sinned and was disposed to do evil. ${ }^{73}$

On the other hand, Re, the righteous god who abominates injustice, vents his wrath on the land where oppression prevails. The consequences of his wrath are severe. Thus, he

\footnotetext{
68 Pinch 2004: 115.

${ }^{69}$ Borghouts 1978: 56, n. 211. This magical conjuration is inscribed on the pedestal of the statue of Djedher the Saviour, the guardian of the gates of Athribis temple; see: Jelinkova-Reymond 1956: 79, 81, 11. 162-168; see also: Vernus 1978: 193, 322-323.

70 Re is credited with human feelings of anger, bitterness, and pity, see: Pinch 2004: 25.

71 Morenz 1973: 130, n. 86.

72 P. Jumilhac, XII, 23; Vandier 1961: 124, P1. 8.

73 Lichtheim 1976: 106.
} 
makes law, sanctity and justice cease in this land, and makes values scarce in it. ${ }^{74}$ He lets nobody trust in it, he makes great its humble people, and humbles its great people and sets the fools over the wise. ${ }^{75}$

The rage of Re against Apophis aims at repelling and annihilating his harm. It has severe consequences on Apophis, as Re has given the order to carry out his slaughter. The rage and fury of Re also aims at rescuing the life of his daughter Bastet, who was stung by a scorpion. Thus, when he comes with his rage, he assures and asks her not to be afraid, as he is behind her and he is going to slay the poison that is in all her limbs.

\section{POSSIBILITY OF AVOIDANCE AND PACIFICATION}

It is frequently possible to avoid and pacify the wrath of Amun-Re by those who entreat and appeal to him only. This is shown in the texts that praise the god with the purpose of pacifying his wrath in a context of stressing his kindness and tolerance. On the Banishment Stela, he is Highly forgiving, [he] returns quickly to the one who entreats him; he turns back to heal the sick. For [he] watches [over] mankind, without forgetting anyone ( $q(3 j)$ htpy $h n[s w] n$ sn $s w$ ' $n$ sw r snfr mn n ptr=[f $m]$ rmtw $n n m h=f(h m=f) h r n b) .{ }^{76} \mathrm{He}$ agrees to be forgiving toward the quarrelsome servants whom he banished to the oasis. By way of contrast, his wrath against the trespassers and offenders is inevitable. As for $\mathrm{Re}$, the attestations of his wrath do not show any possibility of being avoided or pacified.

\section{LINGUISTIC EXPRESSIONS}

The expression ' $m 3 j h h_{3} 3$ ňny ' $n w t$ ' states that the furious claws of Amun, as a raging lion, inflict severe wounds on the enemies of the god. This evokes the sharp nails of the feline goddesses and those of the deceased, which are like the arrows of Sekhmet (' $n w t=j$ $r=f m$ sšrw Shmt). ${ }^{77}$ As for ' jn-nym $t 3 y=f \breve{s} t=k$ ', it states that the wrath of Amun-Re is inevitable. It evokes the Inscription of the Battle of Qadesh of Ramesses II, where it is said of the king: Who could resist you on the day of your wrath? (m-nym t3y=f tw $h r w$ qnd $=k) .^{78}$ The expression 'jry qnd=f $m \mathrm{~km} n$ 3t $n n$ spyt' states that the god's wrath passes in the twinkling of an eye implying his tolerance and mercy. ${ }^{79}$ As for 'qnd $r$ jqr sp 2', it implies the excessive burst of the god's anger. The expression ' $m k R^{\ulcorner} n s ̌ n ~ h r r$ $h r=s$ ' uses the two words ' $n \check{s} n$ ' and ' $h$ ' $r$ ' to express the extreme fury of Re. Therefore, he ordered the slaughter of Apophis. The same can be said about the usage of the two words ' $h$ ' $r$ ' and ' $h \underline{d} h$ ' as well as the phrase ' $w r$ sp 2' to describe the extreme anger of Re and the Ennead.

\footnotetext{
74 P. British Museum 10508, 4, 20-5, 6; Lichtheim 1980: 163-164.

75 P. British Museum 10508, 5, 7-5, 10; Lichtheim 1980: 164.

76 Banishment Stela, Louvre C. 256, 1. 14; Ritner 2009: 125, 127; see also: Assmann 1975: 71; 1995: 203-204.

${ }^{77}$ CT II, 237b [149]; Carrier 2004a: 358-359; Faulkner 1973: 127. For the aggressive role of the deceased's and feline goddesses' nails, see: Nyord 2009: 273-274.

${ }^{78}$ KRI II, 97, 10 (§ 330); Lichtheim 1976: 71.

79 Faulkner 1972: 286; Nordh 1996: 101.
} 


\section{WrathFul GODdeSSES AS PERSONIFICATIONS OF THE Eye of Re}

\section{ATTESTATIONS}

In chapter 17 in the Book of the Dead, the Sacred Eye of Horus, identified with the Eye of $\mathrm{Re},{ }^{80}$ rages on the day of the fight between Horus and Seth, as the latter inflicted injury on Horus's face. The text of this chapter reads: I lifted up the hair from the Sacred Eye (wd3t) at its time of wrath ( $m$ tr=s nšny). What does it mean? It means the right Eye of Re when it raged against him (jrt pw wnmt nt $R^{\top} m$ nšnyt $=s r=f$ ) after he had sent it out. It was Thoth who lifted up the hair from it when he fetched it in good condition. ${ }^{81}$ Further, the deceased raises up the hair from the Sacred Eye at the time of its wrath, saying: It is the Eye of Re in its wrath (jrt $\left.R^{\complement} p w m n s ̌ n t=s\right) .{ }^{82}$ In Papyrus Bremner-Rhind, it is the Eye of Re that shall rage against Apophis with its wrath ' $d n d n=s t n m d n d n=s '{ }^{83}$ In the late second century AD fable of the Lion in Search of Man, in Leiden Demotic Papyrus I 384, the destructive anger of the Solar Eye has to be balanced by Maat, otherwise the world will be in chaos. ${ }^{84}$

As a cat goddess, Bastet ${ }^{85}$ was closely associated with rage. Therefore, the $b 3 s$-jar of Bastet $^{86}$ is linked to the rage of the goddess. Thus, the ointment inside the jar serves to protect the anointed ones from the goddess's rage. ${ }^{87}$ During the rituals of Confirming the Royal Power at the New Year from the Late period, the king was anointed with the contents of several $b 3 s$-jars or balm jars associated with the goddesses of the Eye of Re. The main purpose of this anointing is to protect the king from the messenger demons $^{88}$ of these goddesses and their rage during the epagomenal days; and therefore, neither the accusations of Sekhmet nor the plague demons of Bastet are against him. ${ }^{89}$ The anointing is the efflux of Wadjet, which protects the king from the Bastet's red

${ }^{80}$ For occurrences of prophylactic texts, dating from the New Kingdom to the Ptolemaic period, which conjure a harmful intervention of the Eye of Re by comparing the king with the son of Sekhmet, who alone is able to escape the fury of his mother, see: Goyon 1974: 75-83.

81 Faulkner 1985: 45; Quirke 2013: 58.

${ }^{82}$ CT IV, 238b-242a [335]; Faulkner 1973: 260; Carrier 2004a: 814-815.

83 P. Bremner-Rhind 25, 7; see: Faulkner 1933: 52; Darnell 2004: 365; Borghouts 2007: 27.

84 Pinch 2004: 73.

${ }^{85}$ Goddesses associated with the cat like Bastet are usually given the epithets of the 'Eye of Re' and 'Daughter of Re'; see: Velde 1982: 131.

${ }^{86}$ The goddess's name means, 'she of the ointment jar', as her name is derived from the name of that jar; see: Pinch 2004: 115.

87 Jorgensen 2015: 142.

${ }^{88}$ In a spell for purifying anything during the plague, the emissaries of Sekhmet and the murderers of Bastet, rage against the face of the one who is identified with Horus. The text reads: May your emissaries (wpwty) be burned, Sekhmet! Let your murderers (h3yty) retreat, Bastet! No year(-demon) passes along to rage against my face! Your breeze will not reach me! I am Horus, (set) over the wandering demons, oh Sekhmet. I am your Horus, Sekhmet. I am your Unique One; see: Borghouts 1978: 17. In a similar spell for warding off the breath of the vexation of the murderers, the incendiaries and the emissaries of Sekhmet, the year demons rage against the one who is vulnerable to die from the plague, as the text reads: Retreat, murderers! No breeze will reach me so that passers-by would pass on, to rage against my face. I am Horus who passes along the wandering demons of Sekhmet; see: Borghouts 1978: 15.

89 P. Brooklyn, 47.218.50, II, 4; see: Goyon 1972: 57, 89, n. 51. 
rage ' $d \check{s} r w$ ' ${ }^{90}$ The hot rage of Bastet is stated at the end of chapter 135 in the Book of the Dead, reading: As for him who knows it (i.e. this spell) on earth, he will be like Thoth, he will be worshipped by the living, he will not fall to the power of the king and the hot rage of Bastet, $\left(\right.$ smm $(t) n(y) t$ B3stt) and he will proceed to a very happy old age. ${ }^{91}$

Bastet's fits of wrath show her terrifying aspect. Thus, Re could not stand in her neighbourhood when she is angry. This is attested in Papyrus Cairo $86637,{ }^{92}$ as it reads: The going forth of Bastet, mistress of ' $n h-T 3 w y$, in front of Re, she is being angry. The god could not stand in her neighbourhood (qnd.tj nn ' $h^{\complement} n t \underline{\text { tr }} m-h 3 w=s$ ).

The rage of Tefnut, the Eye of Re, ${ }^{33}$ is compared to that of Sekhmet in a text in Philae temple, reading: She rages $(n \check{s} n=s)$ as Sekhmet and she is contended $(h t p=s)$ as Bastet. ${ }^{94}$ The rage of Tefnut, ${ }^{95}$ the Sole Eye of Re, is clear when she has known that the creator has grown a new eye in her absence, and Shu is the one who persuades his sister-consort Tefnut. In the Coffin Texts, Shu pacified the soul of Tefnut, who is in the middle of her rage saying: I have calmed the soul of her who burns, I have quietened her who is in the midst of her rage $(\operatorname{sgr}(w) n=(f)$ jmyt-jb dšrr $=s) .{ }^{96}$ Shu is the one who makes the pain of the flame of her who is in the midst of her rage $(j r w ~ m r n s(w) n h r(y) t$-jb dšrr $=s) .{ }^{97}$ Thoth occasionally accompanies Shu or replaces him as a pacifier of Tefnut, as he uses wise words to pacify the goddess..$^{98}$

As a goddess associated with wrath, Mut is identified with Sekhmet and the Eye of Re. ${ }^{99}$ Therefore, the seated statues of Sekhmet, excavated from the Isheru temple of Mut at Karnak, represent the wrathful aspect of Mut and the control of her wrath. ${ }^{100}$ In the Twenty-second Dynasty Inscription of Osorkon I, on the Bubastite Portal at Karnak, the king calls for the 'flame of Mut' to fall on those who violate the decree of the king. ${ }^{101}$ Thus, the goddess's flame is associated with her rage to overcome them. The text reads: As for the one who will upset this command which I have issued, he shall be subject to the ferocity of Amun-Re ( $\check{s}^{\complement} t$ I Imn-R ), the flame of Mut shall overcome him when she rages (shm.n $n b(j) t j m=f n w M w t m n s n=s)$, and his son shall not succeed him, whereas my name will stand firm and endure throughout the length of eternity. ${ }^{102}$

90 P. Brooklyn, 47.218.50, II, 11-14; see: Goyon 1972: 58.

91 Faulkner, Goelet 1998: 23; Carrier 2009: 506.

92 P. Cairo 86637, rt. XV, 1-2; Bakir 1966: 25; Leitz 1994: 134-135, Pl. 15; Meeks 1996: 35, n. 14.

93 Verhoeven 1985: 297.

94 Junker 1911: 32; Capel, Markoe (Eds) 1996: 140, n. 10.

95 For Tefnut in the moment of her fury ( $m$ 3t nšny=f), see: Benedite 1893: 99, 12. For the response of nature to the rage of Tefnut, see: Jay 2016: 118, n. 120.

${ }^{96}$ CT I, 378b-c [75]; Faulkner 1973: 73; Carrier 2004a: 192-193.

97 CT I, 382b [75]; Faulkner 1973: 73; Carrier 2004a: 194-195.

98 Pinch 2004: 72, n. 21.

99 For Mut as the Eye of Re, see: Troy 1997: 301-315.

100 D'Auria 2010: 98.

101 It dates to the eleventh year of Takelot II; see: PM II², 35-36; Ritner 2009: 348.

102 Caminos 1958: 70-71, § 101; Epigraphic Survey 1954: P1. 19, Cols 52-53; Myśliwiec 2000: 55; Ritner 2009: 353, 358 . 


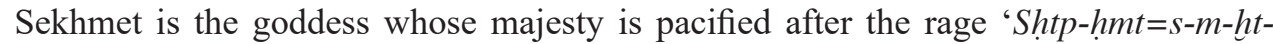
$n \check{s} n y$ ', the appeased one 'Htpt', and lady of rage 'Nbt nšny'. ${ }^{103}$ In the Inscription of the battle of Qadesh, Ramesses II is compared to Sekhmet: he is like Sekhmet in the moment of her fury (mj Shmt $[m] 3 t$ nšny=s). ${ }^{104}$ Ramesses III is the one who gives his blast of fire as a flame against their body ${ }^{105}$ like Sekhmet when she rages (dj hh=f $m$ ht $r h^{\top} w=s h$ mj Shmt hft qnd=s). ${ }^{106}$ Amun addresses Sety I in the triumph scene in the rock temple of Wadi Mia in el-Kanais saying: The terror of you enters their body ${ }^{107}$ like Sekhmet when she rages ( $m j$ Shmt $m$-h ht $n s ̌ n y=s) .{ }^{108}$ In the text of the Great Abydos Stela (Cairo JE 48831), Ramesses IV addresses Sekhmet saying: I have accorded your power among all the gods, mighty is your fury and great your renown among the common folk (wrt $d n d n=t$ ' $\breve{s} 5 \check{s} f=t m-m$ rhyt ), all lands being under your power. ${ }^{109}$ The goddess's wrath may inflict epidemics like plague. This is attested in a text on the North Stela C. 22 of Ramesses II in the Great Temple of Abu Simbel; it reads: Ramesses II who tramples down the Hatti-land, made into heaps the corpses, like Sekhmet raging during a plague (mj Shmt nšny.tj m-h̆t j3d[t]). ${ }^{110}$

Worshippers of Sekhmet lived in fear of the goddess's rage. Therefore, the goddess is addressed in a text in the temple of Edfu reading: O Sekhmet, lady of flame, the one who is in her moment of rage ( $m$ 3t nšny=s), who grasps hearts for herself! ${ }^{111}$ In the Litany of Sekhmet in the temple of Edfu, the goddess is addressed as ' $d \check{s} r-j b$ ', ${ }^{112}$ 'furious' indicating her rage. ${ }^{113}$ She is also described as red-hearted (ďr-jb) against the one from whom she came forth (i.e. Re). ${ }^{114}$

The rage of Maat, the daughter and Eye of Re, ${ }^{115}$ burns the enemies of the great god Amun-Re. In the New Kingdom Papyrus Chester Beatty IV, a hymn to Amun says about Maat: Yours is she, the unique one. She came forth from you, fallen into rage (w3.tj $r^{116}$ nšny), so as to consume them that attack you. ${ }^{117}$

Isis is one of the goddesses who personifies the Eye of Re. ${ }^{118}$ In the temple of Edfu, she puts her rage against the enemies ( $h r w d n s ̌ n=s r h f t y w$ ) of the king. ${ }^{119}$ In the Contendings

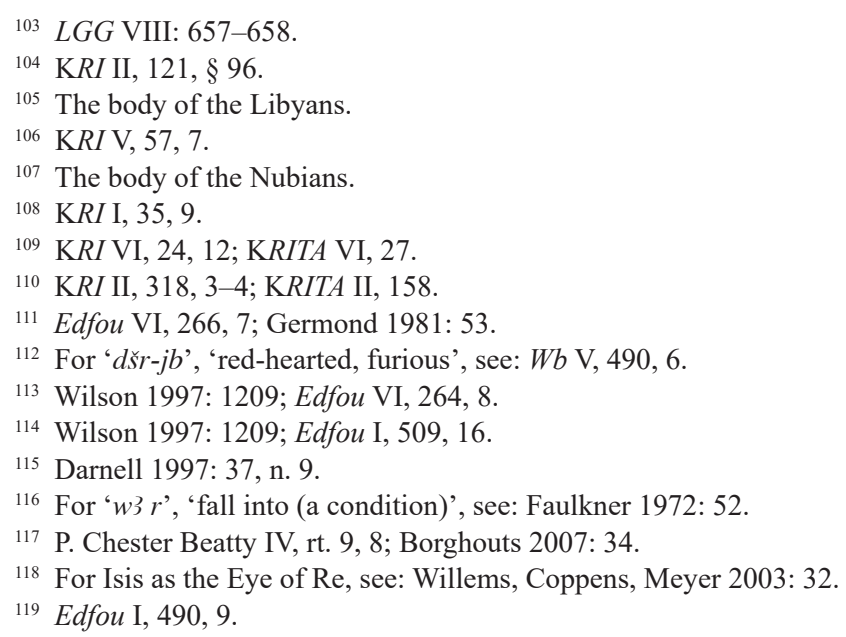


of Horus and Seth, Isis was angry with the Ennead (' $h^{\ulcorner} . n$ 3st qnd $r$ t3 Ps $\left.\underline{d} t\right),{ }^{120}$ and she swore an oath before the Ennead that the case of Horus and Seth must be retried. The gods of the Ennead pacify her saying: Don't get angry (m-jr hdn). Right will be given to him who is right. All that you said shall be done. ${ }^{121}$ For the same reasons, Neith sent a letter to the Ennead saying: Give the office of Osiris to his son Horus, and don't do those big misdeeds that are out of place. Or I shall get angry and the sky will crash to the ground! (jw=j qnd mtw t3 pt $\underline{d}$ hj(.w) $n$ p3 jwtn). ${ }^{122}$ In the temple of Edfu, the gods drive away the rage ' $n$ šny' of Hathor. ${ }^{123}$ The latter puts her rage against the enemies ( $h r$ $w d n s ̌ n=s r h f t y w)$ of the king, ${ }^{124}$ and says to the king: I rage against all the enemies $($ dndn=j $r$ hftyw $n b(w)) .{ }^{125}$

\section{ADDRESSEES}

The sun god Re is an addressee of the wrath of his eye in chapter 17 in the Book of the Dead, while Apophis is the addressee in Papyrus Bremner-Rhind. In Papyrus Brooklyn 47.218.50, Bastet vents her wrath on the king, while in chapter 135 in the Book of the Dead, she vents her wrath on the deceased. In Papyrus Cairo 86637, the rage of Bastet against Re is unbearable. In spell 75 of the Coffin Texts, the rage of Tefnut is addressed to Re. In the above-mentioned inscription of Osorkon I, Mut vents her wrath on the transgressors who violate the decree of the king. The wrath of Sekhmet is frequently addressed to the enemies of the king. Her wrath is also addressed to the common folk and to Re in one occurrence. In the Contendings of Horus and Seth, the addressees of the anger of Isis and Hathor are the gods of the Ennead.

\section{INFLUENCE AND PURPOSE}

The rage of the Eye of Re against Apophis aims at destroying and burning him. The mythological allusion to the reconstitution of the raging Eye of Re is clear in chapter 17 in the Book of the Dead and spell 335 of the Coffin Texts. ${ }^{126}$ The $w \underline{d} 3 t$-eye is the right Eye of Re, which raged against him, when he sent it out on a mission. Thus, the purpose of rage may be explained by the disagreement of the eye to be sent on this mission. The same reason can explain the rage of Tefnut in spell 75 of the Coffin Texts.

Chapter 135 in the Book of the Dead implies that the hot rage of Bastet is dreadful. Therefore, it has to be repelled through the recitation of the spell. The text of Papyrus Cairo 86637 shows that the rage of Bastet is intolerable to the extent that Re cannot tolerate it. As for the rage of Mut, it punishes and overcomes any transgressor who violates the royal decree. Thus, his son shall not take over his office or property.

\footnotetext{
120 P. Chester Beatty I, rt. 4, 10; Lichtheim 1976: 216.

121 P. Chester Beatty I, rt. 4, 12-4, 13; see: Lichtheim 1976: 216; Sweeney 2002: 149.

122 P. Chester Beatty I, rt. 3, 3; see: Lichtheim 1976: 215.

123 Edfou II, 5, 17.

124 Edfou I, 127, 3.

125 Edfou IV, 312, 3-4.

126 For a detailed discussion of these spells, see: Nyord 2009: 229-230.
} 
In different occurrences, the wrath of Sekhmet aims at terrifying and defeating the enemies of the king. This evokes the statement that the horror of the king is like (that of) Seth when he rages ( $n$ rw mj sj $[S t \check{s}] n s ̌ n y=f$ ). ${ }^{127}$ On the other hand, the wrath of Sekhmet aims at submitting the common folk and all the lands. The description of Sekhmet as furious (i.e. red-hearted) against $\mathrm{Re}$ is a reference to her flight from the sun god in the myth of Distant Goddess and the Destruction of Mankind. ${ }^{128}$ The anger of Isis shows her discontent and dissatisfaction because Re-Harakhti wishes to crown Seth instead of Horus. The anger of Neith aims at threatening the gods of the Ennead, if they do not fulfil her demand. Thus, her anger may cause cosmic chaos.

\section{POSSIBILITY OF AVOIDANCE AND PACIFICATION}

There is a possibility of the Eye of Re being pacified by Thoth. However, when she attacks Apopophis, her wrath is inevitable. The wrath of Bastet can be avoided by the king through his anointing by the content of the $b 3 s$-jars. The deceased can also avoid her wrath through the recitation of a chapter from the Book of the Dead. In the myth of the Distant Goddess Tefnut, wine, beer, sistra and music pacify the wrath of the angry lioness goddess. ${ }^{129}$ The sistrum was used to pacify the violent side of a deity, ${ }^{130}$ so that worshippers could approach that deity without provoking his/her wrath. ${ }^{131}$ The sistrum was shacked in the religious rituals of Hathor, with the aim of pacifying 'shtp' her rage. The goddess's pacification refers to an ancient myth known since the New Kingdom, where Hathor, ${ }^{132}$ in her fierce lion-nature, was brought under control. ${ }^{133}$

On the New Year's festival, the Egyptians exchanged the amulets of Sekhmet or Bastet hopefully to pacify the rage of both goddesses. ${ }^{134}$ This is attested in the tradition of the seven arrows of Sekhmet, ${ }^{135}$ which can be traced back to the Middle Kingdom. As personifications of the wrath of the goddess, these entities could bring famine, plague and various infectious diseases especially during the epagomenal days, when plague and fatal diseases afflict humans. ${ }^{136}$ Since the Egyptians feared the goddess's wrath, the Festival of Drunkenness was held to celebrate the liberation of humans from her wrath. ${ }^{137}$

$127 \mathrm{~K} R I \mathrm{~V}, 103,7$.

128 Germond 1981: 90, n. 12.

129 Richter 2010: 162, 173.

130 For the effect of the sistrum on Hathor, see: Bleeker 1973: 60.

131 Capel, Markoe (Eds) 1996: 100. For the presentation of the sistrum to pacify the wrath of god Tutu, see: Kaper 2003: 49.

${ }^{132}$ The feminine word ' $k y t$ ', 'ape' is once used to describe Hathor in the form of the raging Eye of Re; see: $\mathrm{Wb} \mathrm{V}, 110,6$.

133 Chassinat 1934: 100 (vol. 1); 52 (vol. 2); Daumas 1975: 724-727. For an overview of the legends involving the Eye of Re, see: Otto 1975: 562-567; R̈̈RG: 772-773.

134 Pinch 1994: 38-39.

135 The seven arrows of Sekhmet are incarnated as seven messengers who inflict plague and destruction: see: Pinch 2004: 188. They guarantee misfortune, illness, or other negative effects; see: Collier, Quirke (Eds) 2004: 17. See also: Sederholm 2006: 138.

136 Sternberg 1984: 325; Pinch 1994: 38-39.

137 Schneider 2013: 252. 


\section{LINGUISTIC EXPRESSIONS}

In Papyrus Brooklyn, 47.218.50, the word ' $d \check{s} r w$ ', 'wrath' 138 and the expression ' $d \check{s} r-j b$ ', ${ }^{139}$ 'furious' are used to describe the red rage of Bastet and Sekhmet indicating the heat of their wrath. This evokes the usage of the word ' $̌ m m t$ ' to describe the hot rage of Bastet in

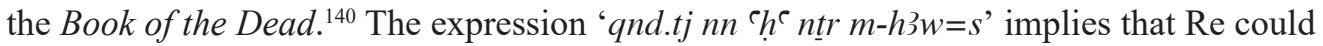
not remain in the neighbourhood of Bastet without risk. ${ }^{141}$ It evokes the words of Sinuhe extolling the prowess of Senwosret I in the battle saying: None can stand in his vicinity $\left(n\left\ulcorner h^{\ulcorner} \cdot n . t w m-h 3 w=f\right){ }^{142}\right.$

The expression 'quietened her who is in the midst of her rage', ' $\operatorname{sgr}(w) n=(f) j m y t-j b$ $d \check{s} r r=s$ ' demonstrates that Tefnut has raised her voice in anger with intense speech, what evokes the raging voice ${ }^{143}$ of Seth in Heliopolis. ${ }^{144}$ This also shows one of the negative effects of expressing anger. The expression 'the flame of Mut shall overcome him when she rages', 'shm.n $n b(j) t j m=f n w M w t m n \check{s} n=s$ ' shows the symbolic relation between fire and divine rage.

The expression 'like Sekhmet raging during a plague', 'mj Shmt nšny.tj $m-h t j 3 d[t]$ ' shows an aspect of Sekhmet as a goddess of plague and pestilence. She inflicts plague illness and death during the five epagomenal days of the year. ${ }^{145}$ In Papyrus Vienna Aeg 8426, the plague of Sekhmet is clear in association with her fury reading: Withdraw your impure one, Sekhmet, may you loosen your arrow, Bastet. Your rage to the ground! This fury of yours which is the plague, Retreat! (...) Her rage is in the cattle. The plague is in the birds, her fury is in the fish in the Nile. ${ }^{146}$

In the expression ' $w 3 . t j r$ ršny', the phrase ' $w$ ' $r$ ' is used to mean falling into a condition. A large number of occurrences of this phrase were collected and in almost all of them, the reference is to the incidence of something evil or negative. ${ }^{147}$

\section{HORUS AND SETH}

\section{ATTESTATIONS}

The dreadful and painful wrath of Horus against the celestial gods ${ }^{148}$ is expressed through his red eyes. ${ }^{149}$ This is attested in utterance 246 of the Pyramid Texts reading:

\footnotetext{
${ }_{138}$ See: Faulkner 1972: 316.

139 The same expression is used in the tomb of Djefay-Hapy at Siut; see: Siut I, 230; Griffith 1889: Pl. 4.

${ }^{140}$ Faulkner, Goelet 1998: 23; Carrier 2009: 506.

${ }^{141}$ Cf. Germond 1981: 69.

${ }_{142}$ Sinuhe B 55-56; Allen 2015: 82.

${ }^{143}$ In Spell 407 of the Coffin Texts, Seth has the epithet ' $q$ 3 hrw', 'loud-voiced'; see: $C T$ V, 215b [407];

Faulkner 1977: 58; Carrier 2004b: 1004-1005.

${ }^{144}$ Leitz 1994: 272.

${ }^{145}$ For texts about the plague of the year caused by Sekhmet; see: Schneider 2015: 545-546.

146 Schneider 2015: 546.

${ }^{147}$ P. Leiden I 344, 3, 13; 7, 2; 9, 6. For example ' $w 3 r$ 3qw', 'fallen into ruin', ' $w 3 r$ šwt', 'become empty', see: Gardiner 1909: 53.

${ }^{148}$ Faulkner 1969: 59, n. 4; Allen 2005: 41.

149 The red colour indicates the hot essence of rage.
} 
The blue-eyed ${ }^{150}$ Horus comes against you, beware of the red-eyed Horus! The one with

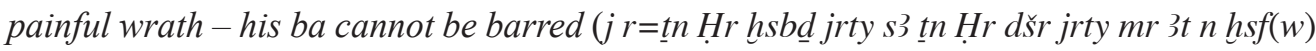
$<b 3\rangle=f$ ). ${ }^{151}$ Further, in the temple of Edfu, the red-eyed Horus rages with/on his face ' $q$ nd $m h r$ ' during the battle. ${ }^{152}$ Horus, lord of the harpoon, rages at all who come to attack ' $d n d n$ $j j n b$ '. ${ }^{153}$ The god may also be angry with humans. In spell 398 of the Coffin Texts, Horus the Lord ascended to the sky angry with men ( $\mathrm{Hr} n b \mathrm{~m}$ prt=f $r \mathrm{pt} \mathrm{s} \mathrm{s} t(. \mathrm{w}) \mathrm{r} r \mathrm{rmt}){ }^{154}$

In chapter 167 in the Book of the Dead: Thoth has fetched the Sacred Eye (wd3t), having pacified the Eye after Re had sent it away. It was very angry (nšn.tj wrt), but Thoth pacified it from anger (Dhwty shtp sy $m$-h̆t w3 sy $r$ nšny) after it had been far away. ${ }^{155}$ In chapter 112, Re asked Horus to look up at the black pig (Seth) and so he looked and then the affliction in his eye raged greatly ( ${ }^{\ulcorner} \cdot n k 3 y w n$ jrt $\left.=f n s ̌ n w ~ w r t\right) .{ }^{156}$

The association between the wrath of Horus, his fierce face and the Upper Egyptian leopard is clearly stated in the Contendings of Horus and Seth. The text reads: Thereupon Horus, son of Isis, was angry with his mother Isis (wn jn Hr s3 3st qnd $r$ mwt $=f 3 s t$ ). He came out, his face fierce like that of a leopard (jw hr=f hşw mj 3by šm'w) and his knife of 16 deben in his hand. He cut off the head of his mother Isis, took it in his arms, and went up the mountain. Then Isis changed herself into a statue of flint without a head. ${ }^{157}$

On the other hand, Horus has the ability to overcome wrath. On the right side of the statue of Naples Museum, the ram-headed ithyphallic Horus Jmy-Shenut ${ }^{158}$ is Horus great of strength who is prosperous and beats the wrath among those in the water (Hrw 33 phty w3s hwj dndn $m$ jmyw mw). ${ }^{159}$ In an appraisal of the healing words of Horus, on the Ramesside Ostracon Strasburg H 111 [1], the god's magic dispels wrath in the heart 'dr qndt jb' and soothes. ${ }^{160}$ In the temple of Edfu, Horus Behdety addresses the king saying: I drive away the raging one $(d r d n d n)^{161}$ from around you. ${ }^{162}$ Further, Horus Behdety protects the body of the king from the rage of the gods ' $r$ qnd ntrw'. ${ }^{163}$

By the end of the Old Kingdom, Seth was regarded as the incarnation of anger in the Osirian theology. ${ }^{164}$ Seth has the epithet '3 $d$ ', 'furious or angry one'. ${ }^{165}$ At the beginning

150 'Blue-eyed Horus' is also attested in $C T \mathrm{~V}, 376 \mathrm{e}-\mathrm{f}$ [467], where the deceased says: Heads are given to me, and I knit on the head of the Blue-eyed Horus (Hr hsbd), one who acts according to his desire; see: Faulkner 1977: 96.

151 PT 246, § 253a-b; Faulkner 1969: 59; Allen 2005: 41; Carrier 2010b: 2728-2729.

${ }^{152}$ Edfou III, 179, 5.

${ }_{153}$ Edfou V, 214, 20.

${ }^{154}$ CT V, 150c-151a [398]; Faulkner 1977: 35; Carrier 2004b: 962-963.

${ }^{155}$ Faulkner 1985: 162; Quirke 2013: 405.

${ }^{156}$ Quirke 2013: 250.

${ }_{157}$ P. Chester Beatty I, rt. 9, 9-9, 10; Lichtheim 1976: 219; Simpson (Ed) 2003: 98.

${ }_{158}$ For further information and references about this god, see: $L G G \mathrm{~V}: 244-245$.

159 Naples Museum 1065; Kákosy 1999: 152.

160 O. Strasburg H 111 [1], 7; Spiegelberg 1922: 70; Borghouts 1978: 75.

${ }^{161}$ It is an epithet of Seth; see: Wilson 1997: 1202.

${ }^{162}$ Edfou VI, 52, 10.

${ }^{163}$ Edfou I, 473, 16.

164 Jong 2001: 101.

${ }^{165} \mathrm{~Wb}$ I, 24, 20-22; Wilson 1997: 27-28. 
of his fight with Horus, the voice of Seth in the sky and in the earth is full of great rage ' $h r w=f m p t h r w=f m t 3 m n s ̌ n t ~ ' 3 t$ ' ${ }^{166}$ Therefore, Seth is associated with the hippopotamus and its features and notably its loud roar, aggression, and savage rage in attack. On the Nineteenth Dynasty first Hittite Marriage Stela of Ramesses II, the ruler of Hatti spoke to his army and his high officials saying: What a situation! Our land is ruined, our lord Sutekh is angry with us (Swth špt $\left.\left.m{ }^{-}{ }^{C} . w\right)=n\right) .{ }^{167}$ On the Rhetorical Stela of Ramesses II, it is said of the king: Victorious King, valiant in battle, powerful one who fights myriads, overthrowing on his right, slaying on his left, like Seth in his moment of rage (mj Stš $m 3 t=f n \check{s} n(. y)) .{ }^{168}$ In the inscriptions of Sety I's campaign to Qadesh and Amurru at Karnak, it is said of the king: angry (nšny) [like Seth, son of] Nut. ${ }^{169}$

Seth personifies the anger of Re as a protector of the sun god. ${ }^{170}$ In the Contendings of Horus and Seth, the latter flies into a rage four times. ${ }^{171}$ He was exceedingly angry " ${ }^{\text {" }}$ '.$n$ Sth qnd $r \underline{d} w$ ' $3 w r$ ' with Atum and Re-Harakhti, as they asked the Ennead to place the White Crown on the head of Horus and to give him the seat of Osiris. ${ }^{172}$ Then, the Ennead said to him: Why are you angry? (j.jrj=k qnd hr-jh?) Should one not act according to the word of Atum, Lord of the Two Lands, the Heliopolitan, and Re-Harakhti? ${ }^{173}$ When the White Crown was placed on the head of Horus, Seth cried out aloud to the Ennead in anger (' $h^{\top} \cdot n$

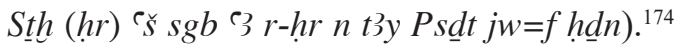

Further, when the gods of the Ennead pacified Isis, asking her not to get angry as right

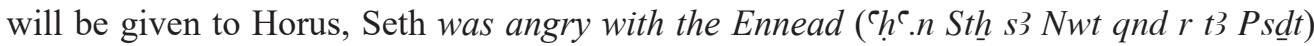
because of the words they had said to her. ${ }^{175} \mathrm{He}$ also became very angry 'Sth qnd r jqr sp 2' when Thoth said to the semen of Horus Come out from, the top of his head. ${ }^{176}$ Then it came out as a golden sun-disk on the head of Seth. ${ }^{177}$

As a god of storm and thunder, Seth is provoked into anger when he is fighting another god. The god's rage is evident when he is fighting Apophis, ${ }^{178}$ as he raises a tumult of storm ' $\breve{s} d(w)$ hnnwt(y)w', in the horizon. ${ }^{179}$ Thus, Seth is raging at the prow of the sun barque (Sth $n s ̌ n y(. w) m h 3 t=s k j t j w j 3) .{ }^{180}$ His rage is associated with the sea, and storms. Thus, the destructive rage of the sea, as a storm, was explained by the rage of Seth. ${ }^{181}$

166 Leitz 1994: 272; see also: P. Cairo 86637, rt. XV, 9; Bakir 1966: 25.

167 KRI II, 246, 7-10; KRITA II, 93.

$168 \mathrm{KRI}$ II, 289, 6; KRITA II, 118.

$169 \mathrm{~K} R I \mathrm{I}, 24,10$.

170 Hoens 1982: 25.

171 P. Chester Beatty I, rt. 4.13-5.1, 8.5, 12.12, 13.1; see: Sweeney 2002: 149; Leitz 1994: 272.

172 Lichtheim 1976: 218.

173 P. Chester Beatty I, rt. 8, 5; Lichtheim 1976: 218.

174 P. Chester Beatty I, rt. 8, 6-7; Lichtheim 1976: 218.

175 P. Chester Beatty I, rt. 4, 13-5, 1; Lichtheim 1976: 216.

176 The head of Seth.

177 P. Chester Beatty I, rt. 12, 12; Lichtheim 1976: 220.

178 Epigraphic Survey 1930: Pls 32, 5; 46, 31; Velde 1967: 101.

179 Chapter 39 in the Book of the Dead; see: Faulkner 1985: 61; Carrier 2009: 167; Velde 1967: 101.

$180 \mathrm{KRIV}, 42,3$.

181 Collombert, Coulon 2000: 207, n. 33. 
In only one attestation in spell 607 of the Coffin Texts, Osiris repelled Seth in his rage ' $h s f$ Sth $m n s \check{n}=f$ '. ${ }^{182}$

In the Ramesside Leiden Magical Papyrus I 343, the Sethian rage could be used in a magical context: The rage of Seth is directed against the akhu-disease (khb $n$ Stš $r$ p3 Chw)! The fury of Seth is directed against you ( $\underline{d} n \underline{d} n n$ Strs $r=k)$ ! The rage of the tempest, as it is greedy of water from the sky, is directed against you! $!^{183}$

Before the creation of the universe, anger, noise, strife, tumult, Horus and Seth had not come into existence. ${ }^{184}$ This is attested in the Pyramid Texts, where anger is linked to the fight between the two gods. Thus, the king is the one who belongs to the first generation for punishment(?) and for vindication, which was born before anger came into being (ms.t(j) $n$ hpr.t( $(w) \underline{d n d)}$; which was born before noise came into being; which was born before strife came into being; which was born before tumult came into being; which was born before the Eye of Horus was gouged out, before the testicles of Seth were torn off. . $^{185}$

In a reference to the injured $w \underline{d} 3 t$-eye of Horus in his fight with Seth, in the Pyramid Texts, the $w d 3 t$-eye ${ }^{186}$ belongs to the king and it will not be given over to the rage of Seth

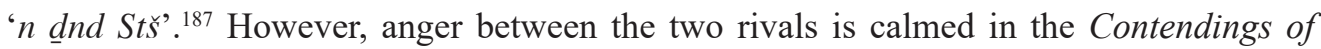
Horus and Seth. In spell 7 of the Coffin Texts, the vindication of the deceased against his foes is brought about in the realm of the dead. It is stated with a reference to the end of the fight between the two rivals Horus and Seth, reading: The fighting is ended, the tumult is stopped, the fire, which went forth, is quenched, the anger in the presence of the Tribunal of the God is calmed $(j d(w) d \check{s} r w$ tp- 'wy d 3 d $33 t$ t ntr $(y) t) .{ }^{188}$

Further, a text in chapter 182 in the Book of the Dead states the pacification of Horus and Seth. It reads: I am Thoth; I have pacified Horus, I have calmed the two comrades in their time of raging (shrj.n=j rhwy $m$ 3t=sn nšny); I have come and have washed away the blood, I have calmed the tumult and have eliminated everything evil. ${ }^{189}$ In a hymn addressed to Osiris in chapter 183, it is said of Thoth that he has pacified the Rival gods (i.e. Horus and Seth) for you (i.e. Osiris), he has removed the raging (dr. $n=f n=k n s ̌ n y)$ and the tumult for you and he has removed anger from their hearts for you $(d r=f n=k \breve{s p t} r j b=s n) .{ }^{190}$

\section{ADDRESSEES}

The painful wrath of Horus is directed to the celestial gods. His anger is also directed to mankind, enemies of the king and his mother Isis. The anger of Seth, in the Contendings of Horus and Seth, is addressed to the Ennead, Atum, Re-Harakhti and Thoth. It is

\footnotetext{
182 CT VI, 2191-220b [607]; Faulkner 1977: 195-196, n. 6.

183 P. Leiden I 343, rt. IV, 9-V, 2; see: Massart 1954: 16-17, 64-65; Collombert, Coulon 2000: 207, n. 33.

184 Grapow 1931: 34-38; Meeks 1996: 14.

185 PT 570, §§ 1462-1463; Faulkner 1969: 225; Carrier 2010b: 2074-2075; Velde 1967: 33.

${ }^{186}$ For the wound of Horus's injured eye, inflicted by Seth, see: CT II, 340b [157]; Faulkner 1973: 135.

187 PT 562, § 1407; Allen 2005: 173; Faulkner 1969: 218.

188 CT I, 21a-c [7]; Faulkner 1973: 3; Carrier 2004a: 10-11.

189 Faulkner 1985: 181; Quirke 2013: 469.

190 Allen 1974: 201; Faulkner 1985: 184.
} 
frequently addressed to the enemies of the king. As a beneficial god, his rage and fury are addressed to the $C h w$-disease and Apophis. In spells of the Book of the Dead, Horus and Seth rage against each other.

\section{INFLUENCE AND PURPOSE}

The aim of the wrath of Horus against the gods is to make them fear and respect him. This is later attested in utterance 246 of the Pyramid Texts as it is said of Horus that none can withstand his might, his messengers go and his couriers run. ${ }^{191}$ The wrathful $w d z t$-eye of Horus incarnates the fury of the creator Re as his divine messenger against his enemies. ${ }^{192}$ In the Contendings of Horus and Seth, Horus was angry with Isis and he cried out aloud because her harpoon bit into his body when he and Seth transformed themselves into hippopotami and plunged into the sea. Further, she felt sorry for Seth, when her harpoon bit into his body. Therefore, Horus's anger resulted in the decapitation of Isis.

The roaring voice of Seth is full of great rage in his fighting with Horus and aims at scaring him. ${ }^{193}$ His wrath against the $w d \underline{d} t$-eye resulted in its injury. His rage against the ruler of Hatti and his army has severe consequences. Thus, the ruler of Hatti says: the sky sheds no rain upon us, every foreign country is hostile, fighting against us all together. ${ }^{194}$ The king is compared to Seth in his rage and power resulting in defeating and overthrowing his enemies. Thus, he is the young bull, strong in battle like Seth when he rages (mj Sth hft nšny=f). ${ }^{195}$ Seth's rage against the Ennead, Atum, Re-Harakhti and Thoth aims at expressing his discontent and frustration because of their desire to give the office of Osiris to Horus and crown him as a king. His rage and fury also aim at exorcising the malign ${ }^{h} \mathrm{~h} w$-disease from the body.

\section{POSSIBILITY OF AVOIDANCE AND PACIFICATION}

The wrath of Horus against the celestial gods is dreadful and inevitable without any possibility of pacification. On the other hand, there is a possibility of pacifying his wrathful eye. There is also a possibility of pacifying the rage of both Horus and Seth in their fight. This role is usually attributed to Thoth. As for Horus, he lost his temper and because of his rage, he chopped off the head of Isis. ${ }^{196} \mathrm{He}$ takes revenge on his mother because of the accidental wound that he received without any possibility of his wrath being avoided or pacified.

As for Seth, there is no possibility or attempt to avoid or pacify his wrath, except for two attestations; one of them states that his rage can be avoided and repelled by Osiris. The other states that Horus Behdety drives away the raging one, Seth.

\footnotetext{
${ }_{191}$ PT 246, § 253a-b; Faulkner 1969: 59.

192 Quirke 2013: 405.

${ }^{193}$ For the terrifying rage of Seth, see: KRI V, 30, 9-10.

194 KRITA II, 93.

$195 \mathrm{~K} R I \mathrm{~V}, 57,8-9$.

196 Meeks 1996: 76.
} 


\section{LINGUISTIC EXPRESSIONS}

The painful wrath ' $m r$ 3t' shows the physical effect of Horus's rage, which may cause painful injuries. It demonstrates the association between pain and rage as unpleasant feelings. The expressions ' $n s ̌ n . t j ~ w r t$ ', 'qnd $r$ jqr sp 2', and ' $q n d r \underline{d} w$ ' $3 w r$ ' show the exceedingly high level of divine anger, when a god loses his temper and has fits of rage. A similar expression is used in the Tale of the Doomed Prince in Papyrus Harris 500, where the prince of Naharin became exceedingly angry ' $h r$ qndt ' $3 t$ wrt'. ${ }^{197}$ The expression ' $h w j d n d n$ ', 'beat wrath' implies that wrath is an enemy who should be defeated and smitten. ${ }^{198}$ As for the expressions ' $d r$ qndt $j b$ ', ' $d r . n=f n=k n s ̌ n y$ ' and ' $d r=f n=k \breve{s p t}$ $r j b=s n$ ', they demonstrate that anger is a malign and negative feeling, which should be removed from the heart. It recalls the expression ' $d r \breve{s} p t m j b$ ntr', which was previously discussed.

\section{WRATHFUL DEITIES AS FIERCE ANIMALS}

\section{ATTESTATIONS}

In the Nineteenth Dynasty Tale of the Two Brothers in Papyrus d'Orbiney, the furious reaction of Bata to the attempted seduction by the wife of his brother Anubis is compared to the anger of a leopard. Thus, Bata acts in anger when Anubis's wife desired to know him as a man. She seized hold of him and seduced him saying: Come, let us spend an hour lying together. It will be good for you, and I will make fine clothes for you. ${ }^{199}$ Then, he

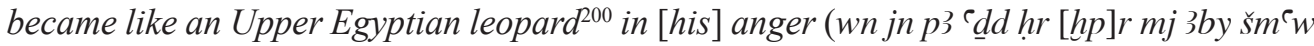
$m$ qnd $[=f]$ ) over the wicked speech she had made to him, and she became very frightened. ${ }^{201}$ The fury of Anubis ${ }^{202}$ and his reaction on account of his wife's report is described in the same way, as he became an Upper Egyptian leopard ' $m j 3 b y$ šm $^{\top} w$ ' ${ }^{203}$ The rage of Seth was also associated with the male leopard, ${ }^{204}$ which incarnates the uncontrolled wrath of the god.

Crocodiles are known as fierce and wrathful reptiles. Thus, the crocodile god Sobek is attested as a wrathful god in the first hymn of the Hymns to Sobek on the Thirteenth Dynasty Ramesseum papyrus VI, where the god is entreated to control and suppress his

197 P. Harris 500 = P. BM 10060, vs. 6, 10; Gardiner 1932: 5; Lichtheim 1976: 201.

198 For ' $h w j$ ', 'defeat (of enemies)', see: Ritner 2009: 471, 481, 1. 31.

199 P. d'Orbiney 3, 7-8; Lichtheim 1976: 204-205; Wettengel 2003: 54.

${ }^{200}$ For further information about leopard in ancient Egypt, see: Störk 1980: 1006-1007.

201 P. d'Orbiney 3, 8-9; Lichtheim 1976: 205; Wettengel 2003: 55; Hollis 2008: 99.

202 Hollis argues that the wrath of Anubis and his pursuit of Bata evokes the negative aspect of his mortuary nature; see: Hollis 2008: 99. The aggressive aspect of Anubis is attested in the Twenty-first Dynasty papyri of Khonsuimhebre and Nesytanebisheru; Anubis is the punisher of the evildoers in the afterlife and the head of seven 3hw-demons responsible for the punishment of sinners and evildoers in the realm of the dead; see: Niwiński 1989: 125, 153, Figs 16, 44 (b-c).

203 P. d'Orbiney 5, 4-5; Lichtheim 1976: 205; Wettengel 2003: 91; Hollis 2008: 99.

204 Seth in Papyrus Jumilhac transforms himself into a panther; see: P. Jumilhac, XIII, 11-13; Vandier 1961: 104. 
wrath reading: Welcome in peace, lord of peace! Quell your fury $(d r \underline{d}$ nd $=k)$, let pass your rage $(s w 3 n s n(y)=k)$, you're a[nger $\left(\check{s} p[t]\right.$ ?) / has been...]. ${ }^{205}$

Taweret is regarded as an ambivalent goddess who has a violent and vengeful aspect on one hand, in contrast to her benevolent and compassionate aspect on the other hand. ${ }^{206}$ This is attested in the text on the Nineteenth Dynasty stela of Penbuy from Deir el-Medina. ${ }^{207}$ The benevolent aspect of the goddess is clear in a part of the text that reads: Beware of her! The day that Taweret is merciful, my heart is in joy. ${ }^{208}$ However, her malevolent and wrathful aspect is evident in another part of the text that reads: Look! Every man who shall live fears Taweret, because her anger is heavier $(d n s \quad b 3 w=s)^{209}$ than a mountain of quartzite. In truth, life is (due to) her mercy. ${ }^{210}$ This text shows that the burden of her anger is intolerable. Therefore, the strength and roaring rage of the goddess were associated with Seth, the god of the wilderness. ${ }^{211}$

\section{ADDRESSEES}

In the Tale of the Two Brothers, the anger of Bata is directed to the wife of Anubis, while the latter's fury is directed to Bata. As for the anger of Taweret on Penbuy's stela, it is addressed to any living individual.

\section{INFLUENCE AND PURPOSE}

The furious reaction of Bata against Anubis's wife made her very frightened. His rage aims at rebuking her for the offensive and wicked speech she had made to him. Anubis's fit of rage urges him to think about killing his younger brother with a spear to take revenge on him as he became convinced that Bata assaulted his wife. The anger of Taweret is intolerable and heavy as it mimics a mountain of quartzite.

\section{POSSIBILITY OF AVOIDANCE AND PACIFICATION}

The wife of Anubis could not avoid or pacify the anger of Bata. Although the Tale of the Two Brothers does not state that the anger of Anubis was pacified, Bata managed to avoid his anger due to his petitions to Re-Harakhti, who rescued him. The appeal to Sobek to quell and control his wrath implies that it is difficult to be pacified. The text of Penbuy's stela states the mercy and wrath of Taweret, with the possibility of pacifying her wrath. This is attested in two statements of the text, which read: May you be merciful, may I see your mercy, $O$ beautiful one who is appeased... If a faithful one commits

${ }^{205}$ P. Ramesseum VI, 9-10 = P. BM EA 10759; Gardiner 1957: 46. The Ramesseum papyrus was found in the shaft of a tomb at the back of the Ramesseum temple.

206 Bruyère 1939: 105-106.

207 The stela dates to the reign of Ramesses II and it is now on display in the Art Gallery and Museum, Glasgow, temp. no. EGNN 683; see: Bierbrier, Meulenaere 1984: 23-29, Figs 1-2.

208 Bierbrier, Meulenaere 1984: 24.

${ }^{209}$ For ' $b 3 w$ ' with the meaning of 'anger', see: Gardiner 1962: 62, n. 3; Assmann 1995: 204, n. 90.

210 Bierbrier, Meulenaere 1984: 24.

211 Jong 2001: 101. 
a fault, the lords are merciful, and She who makes the good, removes the evil and knows the compassion. ${ }^{212}$

\section{LINGUISTIC EXPRESSIONS}

The expression ' $m j$ jby šm $w$ w $q n d[=f]$ ' compares the wrath of both Anubis and Baba to the leopard. This implies the ferocity of their wrath. In ' $s w 3 n s ̌ n(y)=k$ ', 'let pass your rage', the verb $s w 3$ is used to pass or escape something malign. In utterance 386 , of the Pyramid Texts, the king addresses the corrupt one, a malign serpent in the Netherworld saying, You shall pass (sw3) me in R-Přny. ${ }^{213}$ In utterance 524, this verb is used to express that the dead king have escaped from ' $s w 3$ ' $h r$ ' the messengers of Osiris. ${ }^{214}$ Quell your fury ( $d r \underline{d} n d=k$ ) demonstrates that Sobek's wrath should be controlled. It implies that wrath is an enemy or a negative thing that should be suppressed. Therefore, the verb ' $d r$ ' is used to mean 'subdue (enemies)' and 'repress (wrongdoer)'.215

\section{Osiris AND SNAKE GodS OF THE NETHERWORLD}

\section{ATTESTATIONS}

Although there is reasonable evidence that Osiris is a benevolent god, his wrath is malign in his aspect as a wrathful god. ${ }^{216}$ A portal in the realm of Osiris in the Netherworld is being described as a place of wrath. In chapter 146 in the Book of the Dead, the name of the Fourteenth Portal among the secret portals of the House of Osiris in the Field of Rushes is the Lady of Wrath, dancing on red blood (Nbt $\underline{d} n \underline{d} n h b(w) t h r d \check{r} r w){ }^{217}$

On the late Twenty-first Dynasty Abydos Stela, of the great chief Sheshonq for his father Namlot, he invokes Osiris to inflict his wrath on any person who will subtract from his divine offerings. Thus, he says: Any person who will subtract from his divine offerings, whether from his people, from his cattle, his garden, any of his offerings, or any of his funerary service - will you enact your great and powerful wrath against them, against their wives and their children? (jw $=k$ jrt $n 3 y=k b 3 w ~ ` 3 w d r w$ r-r.w $r$ n3y.w hmwt $n 3 y . w$ hrdw). ${ }^{218}$

The disruption of the sacred ceremonies of Osiris can provoke his wrath. In the demotic papyri from Tebtunis temple library, the navigation of Osiris on the night of the $25^{\text {th }}$ of Khoiak is stated at the beginning and end of the Contest for Inaros' Armour, providing an indication to the god's rage. ${ }^{219}$ The Khoiak ceremonies were disrupted or not performed

\footnotetext{
212 Bierbrier, Meulenaere 1984: 24.

${ }^{213}$ PT 385, § 679; Faulkner 1969: 127.

${ }^{214}$ PT 524, § 1236; Faulkner 1969: 196.

${ }^{215}$ Faulkner 1972: 314.

${ }^{216}$ For Osiris as a bellicose god, see: Žabkar 1988: 33; Kákosy 1977: 285-288.

217 The blood in the name of this portal is associated with the Haker-festival; see: Allen 1974: 128, 131, 135; Carrier 2009: 596. In chapter 145, the name of the god who guards the eighth portal of the Weary-hearted one is 'Rager'; see: Allen 1974: 127.

218 Ritner 2009: 169

219 Ryholt 2012: 80.
} 
in their appropriate way, and consequently, this provoked Osiris's rage, to the extent that the god brought about civil war in Egypt. ${ }^{220}$

Although the wrath of Osiris can be provoked, he defends the dead king against the wrath of the deceased. ${ }^{221}$ This is attested in the Pyramid Texts, as the text reads: You (i.e. deceased king) shall summon your ka - namely, Osiris - that he may protect you from every wrath of the dead ( $h w=f k w m^{-}{ }^{-}$dnd $\left.n b n j m(w) t\right){ }^{222}$ It is evident here that the deceased king has the ability to summon Osiris, in the guise of his $k a$, to protect him against the malign wrathful dead in the afterlife. In spell 607 of the Coffin Texts, it is Osiris the great power, born of Geb, who repelled Seth in his rage (hsf $f^{223}$ Sth $\left.m n s ̌ n=f\right)$ and who set over the foreign lands. ${ }^{224}$

Apophis is a malevolent god whose wrath afflicts both the sun god and the deceased. However, in chapter 130 in the Book of the Dead, the deceased breaks Apophis's rage reading: Osiris $N$ has broken the rage of Apophis at Ruty (sd.n=f nšny 'pp hr Rwty). ${ }^{225}$ The rage of Apophis against the deceased is presumably expressed in spell 1099 of the Coffin Texts, as the deceased says about himself: I will not be opposed, the blast of your moment of rage ( $h h n(y) 3 t=k$ ) shall not carry me off, and nothing repellent shall issue from your mouth against me. ${ }^{226}$ The gods' rage against Apophis is attested elsewhere in Papyrus Bremner-Rhind. Thus, the uraei rage ' $d n d n j^{\top} r w t$ ' and fire goes forth against Apophis from the mouths of the wardens of the mysterious portals. ${ }^{227}$ Further, Apophis has fallen by the wrath of his (i.e. Re) uraei ' $h r . t w n d n d n n(j)^{`} r w t=f$ ' and they consume him with the fiery blast of their mouths. ${ }^{228}$ The great Ennead rages against Apophis ' $P s \underline{d} t{ }^{~} 3 t h{ }^{\top} r=s n r=k$ ', ${ }^{229}$ and Horus repelled ${ }^{230}$ the rage of Apophis 'shm.n $\mathrm{Hr} 3 d=k^{\prime}$ '.

The rage of Nehaher ( $N h 3-h r$, horrible of face) is compared to that of Apophis, since both gods are occasionally seen as identical. ${ }^{232}$ Therefore, in TT 255 of Roy, ${ }^{233}$ the royal scribe in the estate of Horemheb, and of Amun, he addresses Re in a Hymn to the Sun saying: I have deflected the anger of Nehaher. ${ }^{234}$ The journey of the meskett boat is

220 Ryholt 2012: 80 .

221 In the Coffin Texts, Orion and Sopdu protect the deceased against the wrath of the malign dead, see: CT I, 188d-e [44]; Zandee 1977: 76; Faulkner 1973: 36; Carrier 2004a: 96-97.

${ }^{222}$ PT 93, § 63b; Faulkner 1969: 21; Carrier 2010b: 2384-2385.

223 For ' $h s f$ ', 'avoid anger', see: Faulkner 1972: 197; Sethe 1928: 80, 16.

${ }^{224}$ CT VI, 2191-220b [607]; Faulkner 1977: 195-196, n. 6.

225 Allen 1974: 106. Faulkner translates it as I have broken up the storm of Apep, O Double Lion; see: Faulkner 1985: 119; Carrier 2009: 483.

${ }^{226}$ CT VII, 411c-412b [1099]; Faulkner 1978: 155-156, n. 28; Carrier 2004c: 2276-2277.

227 P. Bremner-Rhind 26, 10; Faulkner 1933: 57.

228 P. Bremner-Rhind 31, 27; see: Faulkner 1933: 86; 1938: 46

229 P. Bremner-Rhind 32, 1; Faulkner 1933: 86; 1938: 46.

${ }^{230}$ For 'shm', 'repel', see: $W b$ IV, 215, 2-7.

231 P. Bremner-Rhind 23, 21; Faulkner 1933: 48; 1937: 169.

232 El-Sayed 1981: 120, 129.

$233 \mathrm{PM} \mathrm{I}^{1}, 340$.

${ }^{234}$ Nehaher is a common epithet of Apophis and Seth. In spell 236 of the Coffin Texts, Nehaher is addressed in conjunction with the 'messengers of Osiris', 'wp(w)tyw Wsjr' as demons who act against the blessed dead, as they close the mouths of the dead; see: CT III, 304f [236]; Faulkner 1973: 185; Carrier 2004a: 574-575. 
successful daily (hsf. $n=j 3 t N h 3-h r$ hpr sqdwt $m$ Msktt). ${ }^{235}$ In contrast to the evil wrath of Nehaher, in association with Apophis, he defends the sun god through his rage. In the Book of Caverns, the rage of Nehaher as a protector of Re is attested, where the snake in the First Division is Nehaher, lord of rage (Nh3-hrr nb nšny), he devours the life of the rebels of $R^{2} .^{236}$

In another attestation, the deceased addresses the Rerek-snake in chapter 149 in the Book of the Dead saying: Fall! Lie down! May your hot rage be in the ground (hr sdr šmmt=k $m$ t3), may your lips remain in the hole! The bull falls to the snake and the snake falls to the bull, but I am protected, for your head is cut off by Mafdet. ${ }^{237}$

Mehen is another snake who rages. This can be attested in chapter 71 in the Book of the Dead, as it reads: O punisher with his two legs in his raging moment, Mehen-serpent ( $j$ njkw $m r d w y=f m$ 3t=f $m h n t$ ), ba who is amongst his fledglings! ${ }^{238}$

\section{ADDRESSEES}

Osiris vents his wrath on the offenders of gods who subtract from their offerings. He also inflicts his wrath on the land of Egypt. In Papyrus Bremner-Rhind, the addressee of the gods' rage is Apophis. The anger of Nehaher is addressed to the sun god Re. On the other hand, in the above mentioned spell 1099 of the Coffin Texts and chapter 130 in the Book of the Dead, the addressee of Apophis's wrath is the deceased. In chapter 39 in the Book of the Dead, the rage of the Rerek-snake is directed against the deceased. In chapter 71 in the Book of the Dead, the Mehen-serpent is appealed to, in his raging moment, by the deceased.

\section{INFLUENCE AND PURPOSE}

The invocation of Osiris's wrath on Abydos stela of the great chief Sheshonq, has great and powerful influence against the offenders, their wives and their children.

It is evident that the rage of the snake gods has no influence on the deceased. The statement of their rage, however, has significant purpose. In chapter 130 in the Book of the Dead, the deceased addresses Re declaring that he broke the rage of Apophis at Ruty, the two lions forming together the horizon, whence the sun rises. The purpose of his act is to rescue Re from Apophis every day, and consequently, that malign snake cannot attack him. ${ }^{239}$ The same act is taken by the deceased against the rage of Nehaher. Thus, he supports Re in his night journey. On the other hand, the rage of Nehaher devours the life

235 Assmann 1983: 302 (STG Text no. 219); 1995: 33. Nehaher in this text is likely an epithet of Apophis. This is attested in the Seventh Hour of the Book of Amduat, as Apophis appears in the middle register with the name Nehaher; see: Hornung, Abt 2007: 232.

236 Waitkus 1997: 210; El-Sayed 1981: 130.

237 Faulkner 1985: 144. Chapter 39 is another spell for driving off the Rerek-snake in the god's domain; see: Allen 1974: 46. For further information about the snake and his occurrences in the books of the afterlife, see: Borghouts 2007: 21-23.

238 Maspero 1908-1914: 171, 191; Manassa 2007: 181.

239 Faulkner 1985: 119. 
of the rebels of Re in the Amduat. This evokes the role of Seth as a guardian of the solar barque and slayer of Apophis, ${ }^{240}$ since both gods are seen as identical. ${ }^{241}$

The rage of the gods against Apophis in Papyrus Bremner-Rhind is frequently followed by his destruction and annihilation, showing the destructive power of their rage. This is exemplified in an incantation against Apophis that reads: You will fall to Re, you will fall to the rage of his moment ( $h r=t n n R^{e} h r=t n n d n d n n 3 t=f$ ). You will be annihilated for him, you will be annihilated! He shall destroy you, fell you, cut you off; he shall condemn you, execute you, obliterate your names and cut up your soul. ${ }^{242}$

In spell 1099 of the Coffin Texts, the deceased states that the blast of Apophis's moment of rage shall not stop him implying the defeat and opposition of the giant snake at his hands. Therefore, he later states that he will go aboard the barque of Re. ${ }^{243}$ On the other hand, in chapter 71 in the Book of the Dead, the Mehen-serpent, in his raging moment, is appealed in order to make the deceased healthy, release him and cause him to be beloved. ${ }^{244}$

\section{POSSIBILITY OF AVOIDANCE AND PACIFICATION}

There is no possibility of avoiding the wrath of the portal in the realm of Osiris. The wrath of Osiris on the stela of the great chief Sheshonq and the demotic papyri from Tebtunis temple is inevitable. It is evident that the rages of Apophis, Nehaher and the Rerek-snake are defeated and avoided by the deceased. On the other hand, the rage of the gods against Apophis is inevitable, destructive, and dreadful, without any possibility of pacification.

\section{LINGUISTIC EXPRESSIONS}

The expression 'sd nšny 'pp', 'break the rage of Apophis', evokes the breaking of the red jars ' $s d d s r w$ ', which inflicts terror on the enemies. ${ }^{245}$ The association between the ritual of breaking the red jars and the slaughter of the bull symbolises the repelling and dismemberment of the enemy. ${ }^{246}$ Further, the red colour of the pots is closely associated with Seth and Apophis. ${ }^{247}$ This may explain the usage of this unusual expression, which probably implies the repelling and destruction of Apophis.

The expression ' $h r . t w n d n d n n(j)^{\top} r w t=f$ ', '(Apophis) has fallen by the wrath of his (i.e. Re) uraei' implies the defeat and submission of Apophis who is frequently described in Papyrus Bremner-Rhind as the fallen and overthrown one. ${ }^{248}$ It also implies the devouring flame of the uraei to which Apophis will fall. ${ }^{249}$ On the other hand, it is similar to a number

\footnotetext{
${ }^{240}$ Piankoff 1957: 75-76, Fig. 54, P1. 2. For the beneficial role of Nehaher, see: El-Sayed 1981: 127-128.

241 El-Sayed 1981: 131.

242 Faulkner 1937: 170.

243 CT VII, 414c [1099]; Faulkner 1978: 155; Carrier 2004c: 2276-2277.

${ }^{244}$ Faulkner 1985: 71.

245 Ritner 1993: 146.

246 Ritner 1993: 147.

247 Ritner 1993: 147.

248 P. Bremner-Rhind 23, 18; 23, 21; 25, 10; Faulkner 1933: 47-48, 53; 1937: 169-170.

249 In P. Bremner-Rhind 25, 11-12, Apophis will fall to the devouring flame, it will destroy him, and he will not exist; see: Faulkner 1933: 53; 1937: 170.
} 
of threat formulae, where the trespassers fall to the fury of Thoth, the slaughter block of Sekhmet, or to the knife of Amun-Re. ${ }^{250}$ The expression 'shm.n $\mathrm{Hr} 3 d=k$ ', 'Horus repelled your (Apophis') rage' may find explanation in utterance 244 of the Pyramid Texts, where the Eye of Horus is associated with the snake and the ritual of breaking the red jars. ${ }^{251}$ The word 'shm' also means 'smash, destroy'. ${ }^{252}$ It is used in Papyrus Bremner-Rhind where the devouring flame of the uraei destroys Apophis reading: You shall fall to the devouring flame and it shall destroy you ( $h r=$ tn $n$ wnmy shmt $=s$ tn). ${ }^{253}$

As for ' $h r s \underline{d} r$ smmt $=k m t$ ', 'May your hot rage ${ }^{254}$ be in the ground', it implies the burning essence of rage. ${ }^{255}$ This is attested in the statement about the wrath of the uraei of $\mathrm{Re}$, as they consume Apophis with the fiery blast of their mouths. ${ }^{256}$

\section{DISCUSSION}

The theme of divine wrath in ancient Egypt raises many questions, which one should try to answer, namely: Is divine wrath different from that of human wrath? Is it always justified or not? Does divine wrath demonstrate a lack of kindness and tolerance? Who are the addressees of wrath? What are the influences and purposes of the divine wrath? Is it beneficial or harmful? Are there levels of divine wrath? Are there specific linguistic expressions of wrath? Is it only an emotional response to humans' sins, wickedness and transgressions? Is there any possibility of avoiding, or minimising the potential harm and pacifying the wrath of deities? The following discussion aims at analysing the above given corpus of texts in order to find answers for these questions.

\section{Attestations}

The above presented attestations of divine wrath come from various sources and different periods of Egyptian history. They date from the Old Kingdom to the Graeco-Roman period. Thus, it is apparent that the notion of the divine wrath finds a persistent expression in the Egyptian texts. Many of the texts dealing with the divine wrath come from the books of the afterlife, namely the Pyramid Texts, the Coffin Texts and the Book of the Dead. This asserts that divine wrath is a religious belief.

It is clear that the sources of divine wrath match with the roles, spheres of actions and influences of each deity. Attestations of the wrath of anonymous gods mainly come from the books of the afterlife, where the spells are recited to repel that wrath. Most of the attestations of the wrath of Amun-Re come from private monuments dating to the Ramesside and

\footnotetext{
250 Nordh 1996: 66; Morschauser 1991: 23.

${ }^{251}$ PT 244, § 249; Faulkner 1969: 58.

$252 \mathrm{~Wb}$ IV, 215, 9.

253 P. Bremner-Rhind 25, 11-12; Faulkner 1933: 53; 1937: 170.

254 The rage of the Rerek-snake.

255 Sederholm 2006: 192.

256 P. Bremner-Rhind 31, 27; see: Faulkner 1933: 86; 1938: 46.
} 
Third Intermediate Periods and particularly the Twenty-first Dynasty, since it is frequently stated in threat formulae dating to this dynasty. ${ }^{257}$ This shows the divine intervention of the god's wrath in humans' life. The wrath of the sun god Re, mainly come from sources dating to the New Kingdom, Second Intermediate, Late and Ptolemaic periods. They are associated with the mythologies of the sun god, magico-religious texts and his relations with other deities, particularly Apophis.

As for Horus, the sources of his wrath are also closely associated with his mythologies and his contendings with Seth in the books of the afterlife and Papyrus Chester Beatty I. On the other hand, his role in repelling wrath is attested in magico-religious texts, on an ostracon and magical healing statue, in his capacity as a healing god. The wrath of Seth is attested in sources from the Ramesside period, and specifically in the inscriptions of military battles. This is mainly because of his war-like attributes, and therefore, the kings of that period likened themselves to him in the battlefield.

Attestations of the wrath of the Eye of Re and the goddesses who incarnate the destructive wrath of his eye come from sources that describe their mythological roles. They include religious papyri, spells of the Coffin Texts and the Book of the Dead, and inscriptions in Graeco-Roman temples. The wrath of Sekhmet, however, is attested in Ramesside battle inscriptions, due to her war-like attributes as a war goddess.

The wrath of Osiris and the snake deities is mainly attested in the Coffin Texts, the Book of the Dead and Papyrus Bremner-Rhind. The attentions of their wrath match with their religious and mythological roles and their associations with the deceased.

\section{ADDRESSEES}

It is evident that each deity addresses and inflicts his/her wrath on specific addressees for specific reasons, in accordance with his/her mythological roles, sphere of actions and influences. Re, for example, is not attested to inflict his wrath on private individuals, since he does not intervene in humans' life like Amun-Re. ${ }^{258}$ Thus, Re frequently vents his anger on other deities. In mythological contexts, gods vent their anger on each other for various reasons. The mythological texts describe their behaviour for better understating of the world and the realm of gods. Thus, the two rivals Horus and Seth rage against each other in their contendings and Re vents his wrath on Apophis symbolising the contending between righteousness and wickedness. On the other hand, deities vent their wrath on the king, the deceased, the king's enemies, trespassers, offenders, and tomb robbers. In each case, a specific god vents his wrath on the grounds of his provocation and its relation to the god's sphere of action.

257 Lucarelli 2006: 260, n. 60; Morschauser 1991: 203.

${ }^{258}$ For the intervention of the ' $b 3 w$ of Amun-Re' in the humans' life, see: Borghouts 1982: 9, 11, 27-28, 35, 43,45, n. 41. 
The consequences and purposes of divine wrath markedly differ from one god to another in accordance with the god's roles, sphere of actions and influences. They are determined by the god, based on the addressee, the provocation of wrath, the reaction of the god and specifically in case of injury and attack. However, gods may vent their wrath on the king or the deceased without any provocation. For instance, the malevolence of Apophis, Nehaher and Rerek is the reason why they inflict their wrath on the deceased. As deities of war-like attributes, Seth, Sekhmet and Horus terrify and defeat the enemies of the king. As protective goddesses of the king, Hathor and Isis play the same role in the texts of the Graeco-Roman temples. The wrath of Re annihilates and overthrows Apophis. As gods of popular cults, Amun-Re and Thoth ${ }^{259}$ intervene in humans' life and vent their wrath on the trespassers, tomb robbers and evildoers.

In cases of transgressions, offences, and attacks on the gods, their wrath has severe consequences. Thus, they may mutilate, burn, or annihilate the addressee, whether he is another god or a living individual.

\section{PosSIBILITY OF AVOIDANCE AND PACIFICATION}

The possibility of avoiding and pacifying the wrath of deities match with their spheres of action, influence and roles in mythology. Osiris and Horus are the only gods who can repel and drive away the wrath of Seth. Thoth and Shu are the only gods who can pacify Tefnut, the Eye of Re. Thoth is the one who pacifies the $w d 3 t$-eye of Horus. He plays a significant role in appeasing the gods at their moment of rage. This is mainly because he is the pacifier of the gods 'shtp ntrw' ${ }^{260}$ In chapter 182 in the Book of the Dead, he is the 'lord of peace, who calms wrath' ${ }^{261}$ He recites spells for the protection of the divine barque in order to calm the sea in its rage, in its fury $(r$ shtp ym $m 3 t=f m n s ̌ n y=f) .{ }^{262} \mathrm{He}$ can defend the deceased against the wrath of fiery creatures in the Netherworld. This is attested in chapter 71 in the Book of the Dead, as the deceased addresses Horus and Thoth saying: $O$ Horus in the southern sky, $O$ Thoth in the northern sky, pacify for me the raging fiery serpent ( $\operatorname{lntp} n=j$ nst nšny.tj), raise up Maat for me to Him whom she loves, so says Thoth. ${ }^{263}$

Although Thoth is a pacifier of rage, his wrath against tomb robbers is invoked in specific tomb curses. The god condemns the violator to his wrath or the 'flame of Sekhmet', with destruction upon his tomb and his descendants. This is attested in a threat in the Twelfth Dynasty biographic inscriptions of Djefay-Hapy in his tomb at Siut. It reads: As for all

${ }^{259}$ For texts addressed to these gods as pleas for help, see: Sadek 1987: 46. For Amun-Re, see: Assmann 1975: 186.

${ }^{260}$ Quirke 2013: 473.

261 Allen 1974: 197.

262 Edfou VI, 128, 4.

${ }^{263}$ Faulkner 1985: 71; Carrier 2009: 258. 
people, all scribes, all learned men, all the middle and lower orders who raise their voices in this tomb, or who damage its inscriptions or break its statues, will be exposed to the wrath of Thoth, the most swift to anger of all the gods ( $h r=s n n \underline{d n d} n \underline{D} h w t y$ spd wn jmyw ntrw). ${ }^{264}$

On the other hand, the addressees of divine wrath play a role to pacify the angry gods. This also matches with the god's spheres of action and influence. For instance, the gods who vent their anger on the deceased in the afterlife are pacified by the deceased himself.

\section{LINGUISTIC EXPRESSIONS}

The harm of the divine wrath is stated in many expressions, where it is described as painful and as a curse of gods. The removing, averting, repelling, cutting off, passing, beating and breaking the rage of gods clearly imply that the divine wrath is dreadful and malign. The fits of rage and the excessive anger and fury of Re, Re-Harakhti, Seth, and the Ennead are described using the adjectives ' 3 ', ' ' $3 t$ ', ' $w r$ ' and ' $w r t$ ' as well as the phrases ' $r$ jqr sp 2' and 'wr sp 2'.

Although the infliction and repelling of the divine wrath have similar expressions, specific ones are used with each deity, like the expressions which state the tolerant wrath of Amun-Re and describe him as a raging lion and the one whose wrath is great and heavy. The extreme anger of Re is also described using specific expressions and words like ' $h{ }^{\prime} r$ ' and 'dšrw', which imply the hot and burning essence of his wrath. The word ' $n s ̌ n y$ ' is frequently used to express the disturbing and destructive rage of Seth. ${ }^{265}$ It implies his violent and uncontrolled rage, as it also means 'storm, disaster' ${ }^{266}$ This word is used to describe the rage of the $w \underline{d} 3 t$-eye of Horus. It is also attested together with ' $d \check{s} r w$ ' to describe the rage of the two rivals in the Contendings of Horus and Seth. In the latter, the word 'qnd' is frequently used to express the extreme rage of Seth against the other gods. This word is usually determined with a baboon sign, indicating the characteristic fierce and terrifying anger of this animal compared to that of Seth. It is also used to describe the uncontrolled rage of Horus against Isis and his rage in the battle. This word describes the anger of Re-Harakhti against the gods in the Contendings of Horus and Seth.

The words ' $s m m t$ ' and ' $d s ̌ r w$ ' are specifically used to describe the hot rage of Bastet. In a similar context, ' $d \check{s} r-j b$ ', 'red-hearted, furious' describes the rage of Sekhmet. These expressions imply the hot essence of the rage of the two goddesses. The red heart of Sekhmet evokes a text on the Thirtieth Dynasty Naukratis stela (Cairo JE 34002); it reads: The king is furious (lit. red-hearted) when he sees his enemies ( $d \check{r} r$ jb $m 33 . n=f \check{s} n t y w=f) .{ }^{267}$

${ }^{264}$ Tomb of Djefay-Hapy, Siut I, 223-224 = Urk. VII, 53, 7-13; see: Griffith 1889: 9-10, P1. IV; Frandsen 1998: 987, nn. 45-46. The tomb of Puyemre at Thebes contains an almost identical tomb threat, see: Montet 1930-1935: 46-47; Nordh 1996: 143; see also: Silverman (Ed.) 1997: 146; Morschauser 1991: 178.

${ }^{265}$ Wilson 1997: 550.

${ }^{266}$ Faulkner 1972: 140; Wb II, 341, 1-16.

267 Erman, Wilcken, 1900: 128. 
Further, it evokes a text in the tomb of Djefay-Hapy at Siut, where he says about himself that he is furious (lit. red-hearted) when he sees the opponents ' $d{ }^{5} r j b m 33=f t k r(w)$ '. ${ }^{268}$ These examples emphasise that when someone or a deity are provoked into rage their heart becomes red implying their rage.

\section{PROVOCATIONS OF THE DIVINE WRATH}

Humans' transgressions, negative actions, and evildoings provoke the deities' wrath and in some cases, they provoke appropriate punishment and revenge. One of the provocations is telling lies, slander, or falsehood. This is attested in the second story of prince Setne Khaemwas, where the wrath of Amun would afflict the chieftain because he tells lies before the king, his lord. ${ }^{269}$ Discontent can provoke the god's wrath causing his face to enrage. At the time when Osiris-Heryshef was crowned as a king at Herakleopolis, he ascended the throne of Re and all the gods gave him honour. However, Seth bowed down to him though this makes his nose bleed because of suppressed rage. ${ }^{270}$ Injustice is another provocation of the divine wrath. In the Contendings of Horus and Seth, Isis became angry with the gods of the Ennead and Re-Harakhti because they wish to give the office of Osiris to Seth. ${ }^{271}$

Tomb robberies and trespasses provoke the wrath of a number of deities and specifically Amun-Re, Thoth ${ }^{272}$ and Khonsu, ${ }^{273}$ who seek appropriate retaliation. They are attested as punishers of the evildoers and offenders, ${ }^{274}$ and therefore, they threaten and punish the tomb robbers. Further, the offenders of gods who subtract from their divine offerings provoke the divine wrath. ${ }^{275}$

\section{CONCLUSIONS}

The above analysed corpus of the texts seems to testify to the questions given at the beginning of the article. Although deities have some common provocations of wrath, each deity has his/her own triggers, and provocations for what makes him/her wrathful or pacified, in accordance with his spheres of action, influence and roles in mythology. The wrath of Seth and Horus is closely associated with their contendings. The wrath of Re has a strong connection with the Contendings of Horus and Seth as well as with Apophis

${ }^{268}$ Siut I, 230; Griffith 1889: Pl. 4.

${ }^{269}$ Lichtheim 1980: 144, 147.

${ }^{270}$ Pinch 2004: 141.

${ }^{271}$ P. Chester Beatty I, rt., 1. 4.10-11; see: Lichtheim 1976: 216; Sweeney 2002: 149.

${ }^{272}$ In a spell against tomb robbers, the owner of the tomb says: Who speaks evil against these writings, Thoth will be a quarreling companion for him; see: Sottas 1913: 161 .

${ }^{273}$ For the bellicose characteristics of Khonsu, and his epithet 'raging lion, great of roaring', see: Žabkar 1988: 24, 163, n. 32.

${ }^{274}$ For Thoth, see: Zandee 1947: 216-217; for Amun-Re on the Smaller Dakhla Stela, see: Quack 2011: 65; for Khonsu, see: Gardiner 1962: 61.

${ }^{275}$ Ritner 2009: 169. 
and his annihilation. His inevitable wrath is closely associated with justice and moral values. ${ }^{276}$ Therefore, he becomes angry at transgressions and evildoing. The wrath of Amun-Re relates to his popular cult as the god of the individuals. ${ }^{277}$ The wraths of Osiris, Apophis, Nehaher, the Rerek-snake and Mehen are mainly associated with the deceased and the Netherworld. The wrath of the Eye of Re and Tefnut are connected with the myth of the Distant Goddess.

Divine wrath is not restricted to specific deities. Thus, any deity can rage, if he/she was provoked to do so. This includes situations in which they feel threatened or attacked, frustrated, weakened, neglected or treated unfairly.

There is a conceptual basis for distinguishing between the divine wrath and the human anger. Divine feelings and emotions differ profoundly from those of humans in a manner fitting only to deities. Therefore, the divine wrath is distinct from what is generally understood as human anger. The latter can be wicked or righteous by considering its aim, motivation, provocation, and timing. On the other hand, divine wrath is justified in most of the cases.

Humans differ from deities in expressing and venting their anger. Disease, for example represents a characteristic expression of divine wrath. The plague epidemics are attested as one of the consequences of Sekhmet's divine wrath. Unlike deities, the living humans and the deceased cannot vent their anger on the king or on any deity. They cannot vent their wrath on a land or get angry with humankind.

Deities are generally benevolent and approachable. It is not a part of their character to inflict their wrath on each other, humans, or the deceased, unless they are provoked to do that. Thus, the divine wrath is traditionally inflicted on the enemies of the god. ${ }^{278}$

Wrath and beneficence are attested as characteristic features of one god with ambivalent character, namely: Amun-Re, the sun god, Osiris, Horus, Thoth and Seth. They are all attested as gods who inflict and repel wrath. This is likely attributed to their ambivalent characteristics, which show their beneficent and wrathful aspects. These characteristics demonstrate that the ancient Egyptians had no problem in accepting both their negative and positive sides.

The association of Seth with wrath is more prominent than that of any other god. Therefore, his zoomorphic figure is used as the determinative of most of the Egyptian words for wrath. Seth personifies the raging nature, and specifically the sea, storm and thunder. ${ }^{279}$ As a god of ambivalent character, he inflicts his rage to heal diseases and this reveals his benevolent aspect. The latter is attested in his role as a slayer of Apophis and protector of the solar barque of Re. ${ }^{280}$

\footnotetext{
${ }^{276}$ VerSteeg 2002: 33 .

${ }^{277}$ For a detailed discussion of the personal piety of Amun-Re as the god of the individual, see: Assmann 1995: 190-210.

${ }^{278}$ Lucarelli 2006: 260.

${ }^{279}$ At the time when the god thunders he rages with all his might; see: P. Ramesseum II, rt. I 6; Barns (Ed.) 1956: 12.

280 Velde 1967: 99-108.
} 
Due to the various characters and responsibilities of the deities, a remarkable range of assemblages of divine malevolence, including divine wrath, became evident. Thus, wrath became one of the characteristic features of specific Egyptian deities. ${ }^{281}$ Although divine wrath is attested throughout the history of Egyptian religion, it was very common in the Ramesside texts, when the gods became the lords and guards of justice replacing the king. ${ }^{282}$ This is plausibly due to the so-called common phenomenon of personal piety. The latter was a newly introduced style of interaction between individuals and deities reflecting self-choice of specific deities and self-expression of the interactions' themes including divine wrath. ${ }^{283}$ The idea of punishment became evident by the late New Kingdom. This idea mainly takes the form of divine wrath, which can either afflict the deceased or be repulsed by him. ${ }^{284}$

Deities are part of the created world, and therefore, the realm of deities has common features with the world's creatures. Thus, the wrath of specific deities is compared to natural forces namely: the fierce animals, storms, thunder and the sea.

Divine wrath is partly associated with sins and transgressions as provocations, with punishment as the agent carrying out the judgment, and with redemption of those who seek the forgiveness of the wrathful deities. In specific attestations, divine wrath is a retribution and supernatural punishment of the people who commit crimes, trespasses and transgressions. Thus, it is justified to maintain justice and social order. Therefore, in these cases divine wrath is inevitable and has severe consequences on the offenders. The inevitability of the destructive and punishing divine wrath is also evident when the deities are attacked or injured.

Divine wrath is not always justified, as this is attested in the Contendings of Horus and Seth, where Re-Harakhti gets angry with Thoth, Horus and the Ennead. Meanwhile, his anger has no justification as he wishes to give the throne of Osiris to Seth, while Horus is there.

Deities can vent their rage and become angry with each other, but it is not frequently attested that they are engaged in bloody battles, with the exception of specific cases. They are namely: the overthrowing and annihilation of Apophis by the rage of Re, the injury of the Eye of Horus by Seth and the decapitation of Isis by the raging Horus.

Divine wrath can be expressed metaphorically using the words 'šmmt', 'heat' and ' $d \breve{s} r$ ', 'red'285 in a way which shows the hot essence of wrath. Thus, the divine wrath is

281 Divine wrath is also attested in Greek magical papyri. For divine wrath of the Greek deities, see: Betz (Ed.) 1986: 5, 41, 43, 55, 114, 116, 143, 148, 260.

${ }^{282}$ Assmann 1983: 264; 1989: 55-88; 2003: 144, n. 67. The Ramesside period witnessed a great change in the religious practices, as well as the religious decorum and representations with the appearance of the so-called 'personal piety', which reached its peak at that time, resulting in a revolutionary innovation. Expressions of personal piety during the Ramesside period are not restricted to specific monuments, or specific genres, or social groups of people, but they are regarded as a religious conception, which appears on royal or private monuments, literature and art; see: Assmann 1989: 69.

283 Baines 1990: 22.

284 Lucarelli 2006: 260.

${ }^{285}$ For ' $d \check{r} r j b$ ', 'furious, red-hearted', see: $W b \mathrm{~V}, 490,6$. 
associated with the red colour of fire and heat. Red is also associated with the rage of Seth, as it symbolises the fiery heat of his wrath. ${ }^{286}$ Therefore, he is called ' $D \check{r} r$ ', the 'Red One', ${ }^{287}$ and carnelian ' $h r s t$ ' symbolises his wrath because of its red colour. ${ }^{288}$

\section{References}

Allen, J. 2005: The Ancient Egyptian Pyramid Texts, Atlanta

Allen, J. 2010: Middle Egyptian: An Introduction to the Language and Culture of Hieroglyphs, Cambridge-New York

Allen, J. 2015: Middle Egyptian Literature: Eight Literary Works of the Middle Kingdom, Cambridge

Allen, T. 1974: The Book of the Dead or Going Forth by Day. Ideas of the Ancient Egyptians concerning the Hereafter as Expressed in Their Own Terms, SAOC 37, Chicago

Andrews, C. 1994: Amulets of Ancient Egypt, London

Assmann, J. 1975: Ägyptische Hymnen und Gebete. Eingeleitet, übersetzt und erläutert, Die Bibliothek der alten Welt, Zürich

Assmann, J. 1983: Sonnenhymnen in Thebanischen Gräbern, Theben 1, Mainz a/Rhein

Assmann, J. 1989: State and Religion in the New Kingdom, [in:] Simpson, W.K. (Ed.), Religion and Philosophy in Ancient Egypt, YES 3, New Haven, 55-88

Assmann, J. 1995: Egyptian Solar Religion in the New Kingdom. Re, Amun and the Crisis of Polytheism, London-New York

Assmann, J. 2001: The Search for God in Ancient Egypt, Ithaca-London

Assmann, J. 2003: The Mind of Egypt. History and Meaning in the Time of the Pharaohs, Cambridge-London

Aufrère, S. 1991: L’univers minéral dans la pensée égyptienne 1-2, BiEtud 105, Le Caire Baines, J. 1990: Restricted Knowledge, Hierarchy, and Decorum: Modern Perceptions and Ancient Institutions, JARCE 27, 1-23

Bakir, A. 1966: The Cairo Calendar no. 86637, Cairo

Barns, J.W.B. (Ed.) 1956: Five Ramesseum Papyri, Oxford

Beckerath, J. von 1968: Die « Stele der Verbannten » im Museum des Louvre, RdE 20, 7-36

Benedite, G. 1893: Description et histoire de l'île de Philae. Textes hiéroglyphiques. Le temple de Philae, $1^{\text {er }}$ fasc., MMAF 13, Paris

Betz, H. (Ed.) 1986: The Greek Magical Papyri in Translation, Including the Demotic Spells, Chicago-London

286 Griffiths 1972: 84, 89.

${ }^{287} \mathrm{~Wb} \mathrm{~V}, 493,1$ = P. Leiden I, 347, 4, 7. Seth is also called the 'Redhead', ' $d \check{r} r$ nbd'. For the association between Seth and the red colour, see: Sederholm 2006: 192-193. For the malevolent role of red colour and its association with Seth, see: Griffiths 1972: 84, 89; Hornung 1975: 49-64. Seth and his confederates are called 'hooded ones with red coats' in a magical Ramesseum papyrus; see: Gardiner 1955: 13, P1. 41/3.

${ }^{288}$ It is plausible that Horus identifies his own eye with Seth's carnelian stone; see: Griffiths 1972: 86; Aufrère 1991: 216-217 (vol. 1); 554-556 (vol. 2); Andrews 1994: 102. For 'hrst', 'carnelian', see Wb III, 150, $9-15$. 
Bierbrier, M.L., Meulenaere, H.J. de 1984: Hymne à Taouêret sur une stèle de Deir el-Médineh, [in:] Sundries in Honor of Torgny Säve-Söderbergh, Boreas 13, Uppsala, 23-32

Blackman, A.M., Fairman, H.W. 1944: The Myth of Horus at Edfu-II: C. The Triumph of Horus over His Enemies: A Sacred Drama (concluded), JEA 30, 5-22

Bleeker, C.J. 1969: The Religion of Ancient Egypt, [in:] Bleeker, C.J., Widengren, G. (Eds), Historia Religionum: Handbook for the History of Religions 1, Religions of the Past, Leiden, 40-114

Bleeker, C.J. 1973: Hathor and Thoth, Two Key Figures of the Ancient Egyptian Religion, Leiden

Borghouts, J.F. 1978: Ancient Egyptian Magical Texts, NISABA 9, Leiden

Borghouts, J.F. 1982: Divine Intervention in Ancient Egypt and its Manifestation (b3w), [in:] Demarée, R., Janssen, J. (Eds), Gleanings from Deir El-Medîna, EgUit 1, Leiden, 1-70

Borghouts, J.F. 2007: Book of the Dead (39): From Shouting to Structure, SAT 10, Wiesbaden

Bruyère, B. 1939: Rapport sur les fouilles de Deir el Médineh (1934-1935), FIFAO 16/3, Le Caire

Buck, A. de 1935: The Egyptian Coffin Texts. Texts of Spells, 1-75, vol. 1, OIP 34, Chicago Caminos, R.A. 1958: The Chronicle of Prince Osorkon, AnOr 37, Roma

Caminos, R.A. 1964: The Nitocris Adoption Stela, JEA 50, 71-101

Capel, A., Markoe, G. (Eds) 1996: Mistress of the House, Mistress of the Heaven: Women in Ancient Egypt. Exhibition, Cincinnati Art Museum, Cincinnati, Ohio, 5 January 1997, The Brooklyn Museum, Brooklyn, New York, 21 February-18 May 1997, Cincinnati

Carrier, C. 2004a: Textes des sarcophages du Moyen Empire égyptien 1, Monaco

Carrier, C. 2004b: Textes des sarcophages du Moyen Empire égyptien 2, Monaco

Carrier, C. 2004c: Textes des sarcophages du Moyen Empire égyptien 3, Monaco

Carrier, C. 2009: Le Livre des Morts de l'Égypte ancienne, Paris

Carrier, C. 2010a: Textes des pyramides de l'Égypte ancienne II: Textes de la pyramide de Pépy I Ir, Paris

Carrier, C. 2010b: Textes des pyramides de l'Égypte ancienne IV: Textes des pyramides de Mérenrê, d'Aba, de Neit, d'Ipout et d'Oudjebten, Paris

Chassinat, É. 1934: Le temple de Dendara 1, Le Caire

Collier, M., Quirke, S. (Eds) 2004: The UCL Lahun Papyri: Religious, Literary, Legal, Mathematical and Medical, BAR-IS 1209, Oxford

Collombert, P., Coulon, L. 2000: Les dieux contre la mer. Le début du "papyrus d'Astarté" (pBN 202), BIFAO 100, 193-242

Couyat, J., Montet, P. 1912: Les inscriptions hiéroglyphiques et hiératiques du Ouâdi Hammâmât, MIFAO 134, Le Caire

Daressy, G. 1894: Remarques et notes, RecTrav 16, 123-133

Darnell, J.C. 1997: The Apotropaic Goddess in the Eye, SAK 22, 35-48 
Darnell, J.C. 2004: The Enigmatic Netherworld Books of the Solar-Osirian Unity. Cryptographic Compositions in the Tombs of Tutankhamun, Ramesses VI and Ramesses IX, OBO 198, Fribourg

Daumas, F. 1975: Besänftigung, [in:] LÄ I, 724-727

D'Auria, S. 2010: Offerings to the Discerning Eye: an Egyptological Medley in Honor of Jack A. Josephson, Culture and History of the Ancient Near East 38, Leiden

Edel, E. 1984: Die Inschriften der Grabfronten der Siut-Gräber in Mittelägypten aus der Herakleopolitenzeit, Opladen

Edwards, I. 1960: Oracular Amuletic Decrees of the Late New Kingdom 1, Hieratic Papyri in the British Museum 4, London

El-Sayed, R. 1981: Nehaher, BIFAO 81/1, 119-140

Epigraphic Survey 1930: The Excavation of Medinet Habu I. Earlier historical records of Ramses III, Medinet Habu I, OIP 8, Chicago 1930

Epigraphic Survey 1954: Reliefs and inscriptions at Karnak III: The Bubastite Portal, OIP 74, Chicago 1954

Erman, A., Wilcken, U. 1900: Die Naukratisstele, ZÄS 38, 127-135

Eyre, C. 2013: The Use of Documents in Pharaonic Egypt, Oxford

Faulkner, R. 1933: The Papyrus Bremner-Rhind (British Museum No. 10188), BiAeg 3, Bruxelles

Faulkner, R. 1934: The Lamentations of Isis and Nephthys, [in:] Mélanges Maspero I: Orient ancien, MIFAO 66, Le Caire, 337-348

Faulkner, R. 1937: The Bremner-Rhind papyrus-III, JEA 23/2, 166-185

Faulkner, R. 1938: The Bremner-Rhind papyrus-IV, JEA 24/1, 41-53

Faulkner, R. 1969: The Ancient Egyptian Pyramid Texts, Oxford

Faulkner, R. 1972: A Concise Dictionary of Middle Egyptian, Oxford

Faulkner, R. 1973: The Ancient Egyptian Coffin Texts I. Spells 1-354, Warminster

Faulkner, R. 1977: The Ancient Egyptian Coffin Texts II. Spells 355-787, Warminster

Faulkner, R. 1978: The Ancient Egyptian Coffin Texts III. Spells 788-1185 \& Index, Warminster

Faulkner, R. 1985: The Ancient Egyptian Book of the Dead, London

Faulkner, R., Goelet, O. 1998: The Egyptian Book of the Dead: The Book of Going Forth by Day. Being the Papyrus of Ani (Royal Scribe of the Divine Offerings), San Francisco

Frandsen, P.J. 1998: On the Avoidance of Certain Forms of Loud Voices to the Sacred, [in:] Clarysse, W., Schoors, A., Willems, H. (Eds), Egyptian Religion: The Last Thousand Years II: Studies Dedicated to the Memory of Jan Quaegebeur, OLA 84, Leuven, 975-1000

Frankfort, H. 1948: Kingship and the Gods. A Study of Ancient Near Eastern Religion as the Integration of Society \& Nature, Chicago

Frankfort, H. 1949: Ancient Egyptian Religion: An Interpretation, New York

Gardiner, A. 1909: The Admonitions of an Egyptian Sage from a Hieratic Papyrus in Leiden (Pap. Leiden 344 recto), Leipzig 
Gardiner, A. 1911: Egyptian Hieratic Texts I. Literary Texts of the New Kingdom. The Papyrus Anastasi I and the Papyrus Koller Together with the Parallel Texts, Leipzig Gardiner, A. 1932: Late-Egyptian Stories, BiAeg 1, Bruxelles

Gardiner, A. 1957: Hymns to Sobek in a Ramesseum Papyrus, RdE 11, 43-56

Gardiner, A. 1959: A Didactic Passage Re-Examined, JEA 45, 12-15

Gardiner, A. 1962: The Gods of Thebes as Guarantors of Personal Property, JEA 48, 57-69

Germond, P. 1981: Sekhmet et la protection du monde, AegHelv 9, Geneva

Goyon, J.-C. 1972: Confirmation du pouvoir royal au nouvel an [Brooklyn Museum Papyrus 47.218.50], BiEtud 52, Le Caire

Goyon, J.-C. 1974: Sur une formule des rituels de conjuration des dangers de l'année : en marge du papyrus de Brooklyn 47.218.50. II, BIFAO 74, 75-83

Grapow, H. 1931: Die Welt vor der Schöpfung (Ein Beitrag zur Religionsgeschichte), ZÄS 67, 34-38

Griffith, F. 1889: The Inscriptions of Siût and Dêr Rîfeh, London

Griffiths, J.G. 1972: Symbolism of Red in Egyptian Religion, Ex Orbe Religionum 24, Leiden, 81-90

Hannig, R. 2006: Ägyptisches Wörterbuch II. Mittleres Reich und Zweite Zwischenzeit, Teil 1, KAW 112, Mainz a/Rhein

Hoens, D.J. 1982: A Short Survey of the History Egyptian Religion in the Netherlands, [in:] Voss, M.H. van, Hoens, D.J., Mussies, G., Plas, D. van der, Velde, H. te (Eds), Studies in Egyptian Religion Dedicated to Professor Jan Zandee, Leiden, 11-27

Hollis, S. 2008: The Ancient Egyptian "Tale of Two Brothers": A Mythological, Religious, Literary, and Historico-political Study, Oakville

Hornung, E. 1975: Seth, Geschichte und Bedeutung eines ägyptischen Gottes, Symbolon N.F. 2, 49-64

Hornung, E., Abt, T. 2007: The Egyptian Amduat. The Book of the Hidden Chamber, Zürich

Jansen-Winkeln, K. 2007: Inschriften der Spätzeit II. Die 22.-24. Dynastie, Wiesbaden

Jansen-Winkeln, K. 2014: Inschriften der Spätzeit IV. Die 26. Dynastie, Wiesbaden

Jay, J.E. 2016: Orality and Literacy in the Demotic Tales, Culture and History of the Ancient Near East 81, Leiden

Jelinkova-Reymond, E. 1956: Les inscriptions de la statue guérisseuse de Djed-Her-leSauveur, BiEtud 23, Le Caire

Jéquier, G. 1911: Le Papyrus Prisse et ses variantes : papyrus de la Bibliothèque nationale (nos 183 à 194), papyrus 10371 et 10435 du British Museum, Tablette Carnarvon au Musée du Caire, Paris

Jong, A. de 2001: Hippopotami, [in:] Redford, D.B. (Ed.), The Oxford Encyclopedia of Ancient Egypt II, Cairo, 100-101

Jorgensen, J. 2015: Myths, Menarches and the Return of the Goddess, [in:] Nyord, R., Ryholt, K. (Eds), Lotus and Laurel: Studies on Egyptian Language and Religion in Honour of Paul John Frandsen, CNIP 39, Copenhagen, 133-164

Junker, H. 1911: Der Auszug der Hathor-Tefnut aus Nubien, APAW, Berlin 
Kákosy, L. 1977: Ein literarisch-mythologisches Motiv: Osiris als Gott des Kampfes und der Rache, [in:] Assmann, J., Feucht, E., Grieshammer, R. (Eds), Fragen an die altägyptischen Literatur. Studien zum Gedenken an Eberhard Otto, Wiesbaden, 285-288

Kákosy, L. 1999: Egyptian Healing Statues in Three Museums in Italy (Turin, Florence, Naples), Catalogo del Museo Egizio di Torino Monumenti e Testi I, IX, Turin

Kaper, O. 2003: The Egyptian God Tutu. A Study of the Sphinx-god and Master of Demons with a Corpus of Monuments, OLA 119, Leuven-Paris

Kitchen, K. 1986: The Third Intermediate Period in Egypt (1100-650 B.C.), Warminster

Leahy, A. 1982-1983: Two Donation Stelae of Necho II, RdE 34, 77-91

Lefebvre, G. 1926: Herihor, vizir (statue du Caire, no 42190), ASAE XXVI, 63-68

Lefebvre, G. 1949: Rouges et nuances voisines, JEA 35, 72-76

Leitz, C. 1994: Tagewählerei. Das Buch ḩ3t nhḥph.wy $\underline{d t}$ und verwandte Texte 1. Textband, $\ddot{A} g A b h$ 55, Wiesbaden

Lesko, L., Lesko, B. 2002: A Dictionary of Late Egyptian 1-2, Berkeley

Lichtheim, M. 1976: Ancient Egyptian Literature. A Book of Readings II. The New Kingdom, Berkeley-Los Angeles-London

Lichtheim, M. 1980: Ancient Egyptian Literature. A Book of Readings III. The Late Period, Berkeley-Los Angeles-London

Lucarelli, R. 2006: The Book of the Dead of Gatseshen: Ancient Egyptian Funerary Religion in the 10th Century BC, EgUit 21, Leiden

Manassa, C. 2007: The Late Egyptian Underworld: Sarcophagi and Related Texts from the Nectanebid Period, $\ddot{A} A T 72$, Wiesbaden

Maspero, G. 1908-1914: Sarcophages des époques persane et ptolémaïque, Catalogue Général des Antiquités Égyptiennes du Musée du Caire 1, Le Caire

Massart, A. 1954: The Leiden Magical Papyrus, I 343 + I 345, Leiden

Meeks, D. 1996: Daily life of the Egyptian Gods, London

Montet, P. 1930-1935: Tombeaux de Siout et de Deir Rifeh (suite), Kêmi 3, 45-111

Morenz, S. 1973: Egyptian Religion, New York

Morschauser, S. 1991: Threat-Formulae in Ancient Egypt. A Study of the History, Structure and Use of Threats and Curses in Ancient Egypt, Baltimore

Myśliwiec, K. 2000: The Twilight of Ancient Egypt: First Millennium B.C.E., IthacaLondon

Newberry, P.E. 1893: Beni Hassan I, ASEg 1, London

Niwiński, A. 1989: Studies on the Illustrated Theban Funerary Papyri of the $11^{\text {th }}$ and $10^{\text {th }}$ Centuries B.C., $O B O$ 86, Freiburg-Göttingen

Nordh, K. 1996: Aspects of Ancient Egyptian Curses and Blessings. Conceptual Background and Transmission, Uppsala

Nyord, R. 2009: Breathing Flesh: Conceptions of the Body in the Ancient Egyptian Coffin Texts, CNIP 37, Copenhagen

Otto, E. 1975: Augensagen, [in:] LÄ I, 562-567

Piankoff, A. 1957: Mythological Papyri, Texts, BollSer XL/3, New York 
Pinch, G. 1994: Magic in Ancient Egypt, London

Pinch, G. 2004: Egyptian Mythology. A Guide to the Gods, Goddesses, and Traditions of Ancient Egypt, Oxford

Quack, J.F. 1994: Die Lehren des Ani. Eine neuägyptischer Weisheitstext in seinem kulturellen Umfeld, $O B O$ 141, Freiburg-Göttingen

Quack, J.F. 2011: From Ritual to Magic: Ancient Egyptian Precursors of the Charitesion and their Social Setting, [in:] Bohak, G., Harari, Y., Shaked, S. (Eds), Continuity and Innovation in the Magical Tradition, Jerusalem Studies in Religion and Culture 15, Leiden, 43-84

Quirke, S. 2013: Going out in Daylight: prt $m$ hrw. The Ancient Egyptian Book of the Dead: Translation, Sources, Meanings, GHP Egyptology 20, London

Richter, B.A. 2010: On the Heels of the Wandering Goddess: The Myth and the Festival at the Temples of the Wadi el-Hallel and Dendera, [in:] Dolińska, M., Beinlich, H. (Eds), 8. Ägyptologische Tempeltagung, Königtum, Staat und Gesellschaft früher Hochkulturen 3/3, Wiesbaden, 155-186

Ritner, R. 1993: The Mechanics of Ancient Egyptian Magical Practice, SAOC 54, Chicago

Ritner, R. 2009: The Libyan Anarchy: Inscriptions from Egypt's Third Intermediate Period, Atlanta

Ryholt, K. 2012: Narrative Literature from the Tebtunis Temple Library, CNIP 35, Copenhagen

Sadek, A. 1987: Popular Religion in Egypt during the New Kingdom, $H \ddot{A B} 27$, Hildesheim

Sander-Hansen, C. 1956: Die Texte der Metternichstele, AnAeg 7, Kopenhagen

Schiavo, R. 2013: Una lettera al morto per placare l'ira di una defunta: alcune osservazioni sulla coppa di Berlino 22573, EVO 36, 29-38

Schneider, T. 2013: Ancient Egypt Investigated: 101 Important Questions and Intriguing Answers, London-New York

Schneider, T. 2015: Modern Scholarship versus the Demon of Passover: An Outlook on Exodus Research and Egyptology through the Lens of Exodus 12, [in:] Levy, T.E., Schneider, T., William, H.C. (Eds), Israel's Exodus in Transdisciplinary Perspective: Text, Archaeology, Culture, and Geoscience, Quantitative Methods in the Humanities and Social Sciences, Cham, 537-553

Sederholm, V.H. 2006: Papyrus British Museum 10808 and its Cultural and Religious Setting, $P d \ddot{A} 24$, Leiden

Sethe, K. 1928: Ägyptische Lesestücke zum Gebrauch im Akademischen Unterricht: Texte des Mittleren Reiches, Leipzig

Silverman, D.P. (Ed.) 1997: Ancient Egypt, London

Simpson, W.K. (Ed.) 2003: The Literature of Ancient Egypt. An Anthology of Stories, Instructions, and Poetry, New Haven-London

Sottas, H. 1913: La préservation de la propriété funéraire dans l'Ancienne Egypte. Avec le recueil des formules d'imprécation, BEPHE 205, Paris

Spiegelberg, W. 1922: Horus als Arzt, Z̈̈S 57, 70-71

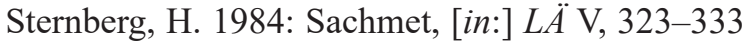


Störk, L. 1980: Leopard, [in:] L̈̈ III, 1006-1007

Störk, L. 1982: Pavian, [in:] LÄ IV, 915-920

Sweeney, D. 2002: Gender and Conversational Tactics in the Contendings of Horus and Seth, JEA 88, 141-162

Thijs, A. 2011: Introducing the Banishment Stele into the $20^{\text {th }}$ Dynasty, ZÄS 138, 163-181

Troy, L. 1997: Mut Enthroned, [in:] Dijk, J. van (Ed.), Essays on Ancient Egypt in Honour of Herman te Velde, Egyptological Memoirs 1, Groningen, 301-315

Vandier, J. 1961: The Papyrus Jumilhac, Paris

Velde, H. te 1967: Seth, God of Confusion. A Study of his Role in Egyptian Mythology and Religion, $P d \ddot{A}$ 6, Leiden

Velde, H. te 1982: The Cat as Sacred Animal of the Goddess Mut, [in:] Voss, M.H. van, Hoens, D.J., Mussies, G., Plas, D. van der, Velde, H. te (Eds), Studies in Egyptian Religion. Dedicated to Professor Jan Zandee, Leiden, 127-137

Verhoeven, U. 1985: Tefnut, [in:] L̈̈ VI, 296-304

Vernus, P. 1978: Athribis : textes et documents relatifs à la géographie, aux cultes, et à l'histoire d'une ville du Delta égyptien à l'époque pharaonique, BiEtud 74, Le Caire

VerSteeg, R. 2002: Law in Ancient Egypt, Durham

Waitkus, W. 1997: Die Texte in den unteren Krypten des Hathortempels von Dendera. Ihre Aussagen zur Funktion und Bedeutung dieser Räume, MÄS 47, Mainz a/Rhein

Wettengel, W. 2003: Die Erzählung von den beiden Brüdern. Der Papyrus d'Orbiney und die Königsideologie der Ramessiden, OBO 195, Freiburg-Göttingen

Willems, H., Coppens, F., Meyer, M. de 2003: The temple of Shanhûr. Volume 1. The sanctuary, the "wabet», and the gates of the central hall and the great vestibule (1-98), OLA 124, Leuven-Paris

Wilson, P. 1997: A Ptolemaic Lexikon. A Lexicographical Study of the Texts in the Temple of Edfu, OLA 78, Leuven

Žabkar, L. 1988: Hymns to Isis in her Temple at Philae, Hanover-London

Zandee, J. 1947: De Hymnen aan Amon van Papyrus Leiden I 350, OMRO 28, Leiden

Zandee, J. 1966: An Ancient Egyptian Crossword Puzzle, MVEOL 15, Leiden

Zandee, J. 1977: Death as an Enemy, according to Ancient Egyptian Conceptions, New York 


\section{ÉTUDES et TRAVAUX XXXI / 2018}

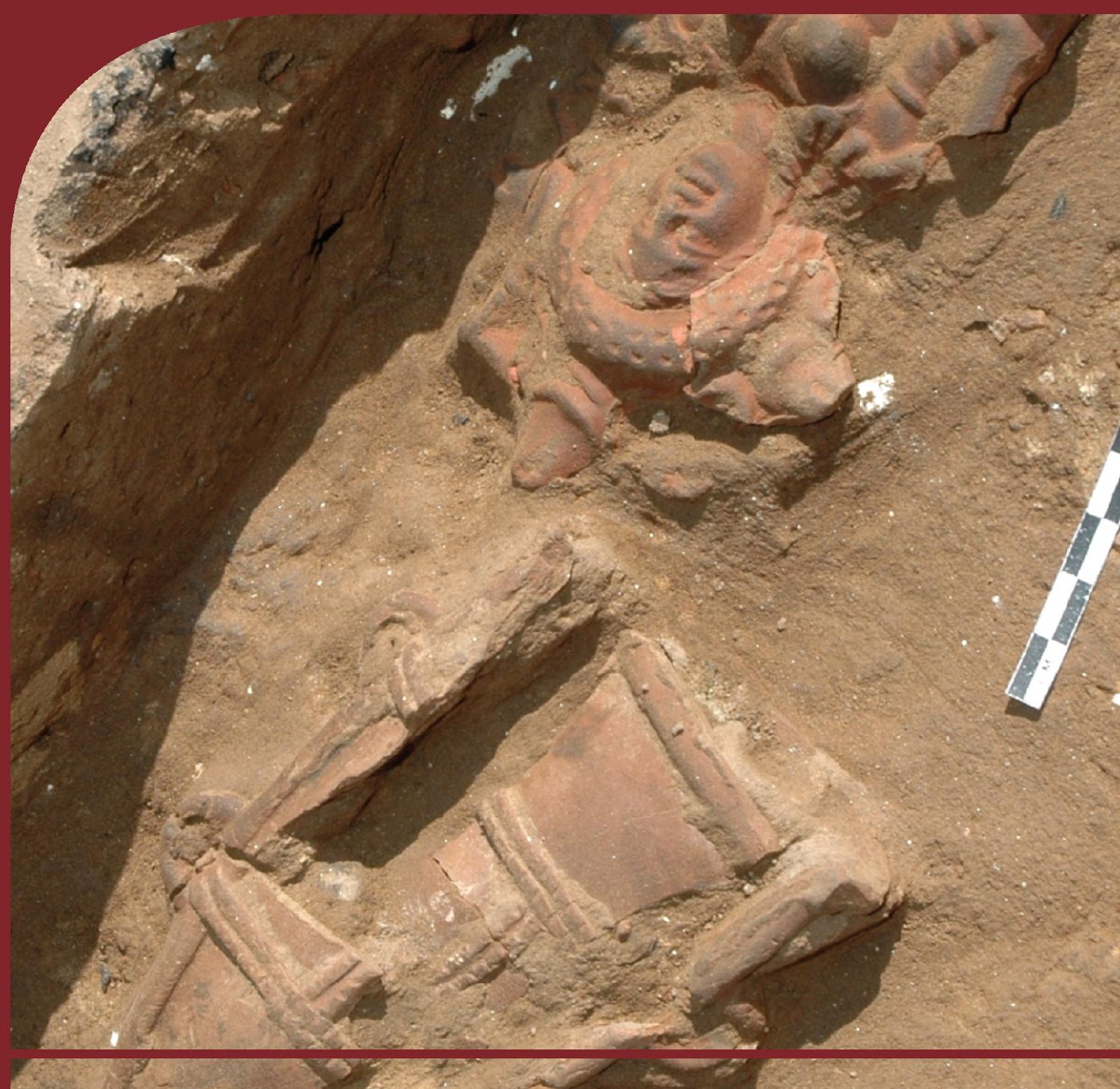

Institut des Cultures iyréditerranéennes et Oilentales FORIKSiO - de PAcadémie Polonaise des Sciences DS PA 


\section{COMITÉ DE RÉDACTION SCIENTIFIQUE}

Maciej Makowski - rédacteur en chef

Jadwiga Iwaszczuk - rédacteur

Mariusz Drzewiecki - sécretaire de la rédaction

Karol Myśliwiec - rédacteur thématique du volume

CONSEIL SCIENTIFIQUE DU JOURNAL

M. Kobusiewicz (IAE PAS, Warszawa), E. Laskowska-Kusztal (IMOC PAS, Warszawa)

D. Michaelides (University of Cyprus, Nicosia)

J.Ch. Moretti (IRAA-MOM, Université de Lyon 2/CNRS)

D. Raue (Ägyptisches Museum der Universität Leipzig), P. Reynolds (ICREA, España)

D. Welsby (British Museum, London)

\section{COMITÉ SCIENTIFIQUE DE LECTURE}

H.D. Baker (University of Toronto), P. Ballet (ArScAn-ESPRI, Université Paris Nanterre),

N. Beaux Grimal (IFAO, Cair/Collège de France, Paris), A. Dodson (University of Bristol),

L. Gabolde (CNRS), C. Gobeil (Egypt Exploration Society, London),

J. Holaubek (Institut für Ägyptologie, Wien), S. Ikram (American University in Cairo),

K. Innemée (Universiteit Leiden), Ch. Leitz (Universität Tübingen),

A. Loprieno-Gnirs (Universität Basel), Ch.E. Loeben (Museen für Kulturgeschichte, Hannover),

S. Ortisi (Universität München), A. Peignard-Giros (HiSoMA-MOM, Université de Lyon 2/CNRS),

E. Rova (Università Ca' Foscari Venezia), A. Sasson (San Diego Natural History Museum),

G. Schreiber (Eötvös Loránd University, Budapest), E. Teeter (University of Chicago),

Y. Tristant (Macquarie University, Sydney), V. Vaelske (independent researcher),

V.W.J. van Gerven Oei (independent researcher), H. Vymazalová (Charles University, Prague),

K. Winther-Jacobsen (Danish Institute at Athens),

J.A. Ostrowski, E. Papuci-Władyka, J. Śliwa (IA JU, Kraków),

R. Czerner (WUST, Wrocław), A. Ćwiek (IA AMU, Poznań),

K. Domżalski (IAE PAS, Warszawa), M. Pinker (FOS UW, Warszawa),

Ł. Niesiołowski-Spanò (IH UW, Warszawa), M. Gawlikowski (PCMA UW, Warszawa), K.O. Kuraszkiewicz (DE FOS UW, Warszawa), M. Barwik, P. Dyczek, W. Godlewski,

S. Rzepka, J. Żelazowski, A. Niwiński (IA UW, Warszawa)

\section{RÉDACTION TECHNIQUE}

Maciej Makowski, Jadwiga Iwaszczuk

CORRECTION LINGUISTIQUE

Jo Harper 
ÉTUDES et TRAVAUX

XXXI 
INSTYTUT KULTUR ŚRÓDZIEMNOMORSKICH I ORIENTALNYCH POLSKIEJ AKADEMII NAUK

\title{
STUDIA i PRACE
}

XXXI

\author{
gO IKŚiO \\ ESA PAN \\ WARSZAWA \\ 2018
}


INSTITUT DES CULTURES MÉDITERRANÉENNES ET ORIENTALES DE L'ACADÉMIE POLONAISE DES SCIENCES

\section{ÉTUDES et TRAVAUX}

XXXI

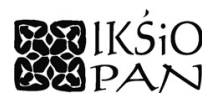

VARSOVIE

2018 
Publication scientifique financée dans le cadre du programme du Ministre de la Science et de l'Éducation Supérieure « Programme National de Développement de l'Humanistique » pour les années 2016-2021 (projet $n^{\circ} 3 \mathrm{bH} 15009983$ )

\title{
Harodowy PROGRAM ROZWOJU HUMANISTYKI
}

\author{
Copyright $($ ) \\ Instytut Kultur Śródziemnomorskich i Orientalnych PAN \\ et les Auteurs \\ Warszawa 2018
}

ISSN 2084-6762

(avant $2011: 0079-3566$ )

e-ISSN 2449-9579

Version première en papier, imprimée en Pologne - 150 copies

Version électronique accessible sur http://www.etudesettravaux.iksiopan.pl

Édition: Polskie Towarzystwo Historyczne et Wydawnictwo Neriton, Warszawa

Conception générale de couverture : J. Iwaszczuk Photo de couverture : P. Moser (C) Schweizerisches Institut für Ägyptische Bauforschung und Altertumskunde in Kairo

(terre cuites d'Aswan/Syene) 


\section{Table des matières}

KAROL MYŚLIWIEC

$(E T=E t u d T r a v / 50) \times 30$

HASSAN Aglan

Hatshepsut and the Apis Race: New Quartzite Relief Fragments

from Dra' Abu el-Naga

Amgad Joseph

Divine Wrath in Ancient Egypt

Amgad Joseph

Pain Infliction, Inflictors and Healers in Egyptian Religious, Magical

and Literary Perceptions

MirosŁaW BarwiK

New Dipinti in the Birth Portico of the Hatshepsut Temple at Deir el-Bahari

KrzyszTOF BorysŁaWsKi, ANNA NiwiŃSKA, ANDRZEJ NiwiŃSKI,

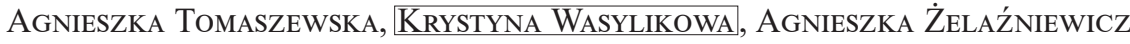

A Bulb of Narcissus on the Egyptian Mummy from University

of Wrocław Collection

LINDA CHAPON

Some Reliefs Representing the King in the Heb Sed Robe Discovered in the Henket-Ankh

Philippe Guillaume

Debunking the Latest Scenario on the Rise of the Pork Taboo

Mariola Hepa

A Clay Gladius Scabbard from Area 13c in the Ancient Roman Town of Syene

Emanuele E. Intagliata

Pinpointing Unrest at Palmyra in Early Islamic Period. The Evidence from Coin Hoards and Written Sources 
KATARZYNA KAPIEC

The Sacred Scents: Examining the Connection Between the ' $n t j w$ and $s f \underline{t}$ in the Context of the Early Eighteenth Dynasty Temples

DOMINIKA MAJCHRZAK

Remarks on the Iconographic Motif of the Birdman in Mesopotamian Glyptic Art of the Third Millennium BC

KAROLINA PAWLIK

Stone Artefacts from Late Roman Occupation Phases in Nea Paphos

ABRÉVIATIONS 
THE VOLUME IS PUBLISHED TO CELEBRATE

THE $50^{\text {TH }}$ ANNIVERSARY

OF THE

ÉTUDES ET TRAVAUX

ESTABLISHED IN 1966 